\title{
REVIEW
}

\section{Genetics of tumors of the adrenal cortex}

\author{
Fidéline Bonnet-Serrano ${ }^{1,2}$ and Jérôme Bertherat ${ }^{1,3}$ \\ 'Institut Cochin, INSERM U1016, CNRS UMR8104, Paris Descartes University, Paris, France \\ 2Hormonal Biology Laboratory, Assistance Publique Hôpitaux de Paris, Hôpital Cochin, Paris, France \\ 3Department of Endocrinology, Assistance Publique Hôpitaux de Paris, Hôpital Cochin, Paris, France \\ Correspondence should be addressed to J Bertherat: jerome.bertherat@aphp.fr
}

\begin{abstract}
This review describes the molecular alterations observed in the various types of tumors of the adrenal cortex, excluding Conn adenomas, especially the alterations identified by genomic approaches these last five years. Two main forms of bilateral adrenocortical tumors can be distinguished according to size and aspect of the nodules: primary pigmented nodular adrenal disease (PPNAD), which can be sporadic or part of Carney complex and primary bilateral macro nodular adrenal hyperplasia (PBMAH). The bilateral nature of the tumors suggests the existence of an underlying genetic predisposition. PPNAD and Carney complex are mainly due to germline-inactivating mutations of PRKAR1A, coding for a regulatory subunit of PKA, whereas PBMAH genetic seems more complex. However, genome-wide approaches allowed the identification of a new tumor suppressor gene, $A R M C 5$, whose germline alteration could be responsible for at least $25 \%$ of PBMAH cases. Unilateral adrenocortical tumors are more frequent, mostly adenomas. The Wnt/beta-catenin pathway can be activated in both benign and malignant tumors by CTNNB1 mutations and by ZNRF3 inactivation in adrenal cancer (ACC). Some other signaling pathways are more specific of the tumor dignity. Thus, somatic mutations of CAMP/PKA pathway genes, mainly PRKACA, coding for the catalytic alpha-subunit of PKA, are found in cortisol-secreting adenomas, whereas IGF-II overexpression and alterations of p53 signaling pathway are observed in ACC. Genomewide approaches including transcriptome, SNP, methylome and miRome analysis have identified new genetic and epigenetic alterations and the further clustering of ACC in subgroups associated with different prognosis, allowing the development of new prognosis markers.
\end{abstract}

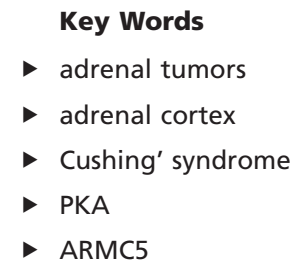

Endocrine-Related Cancer (2018) 25, 131-152

\section{Introduction}

Adrenocortical tumors can be unilateral or bilateral, secreting or non-secreting various types of adrenal steroids depending on tumor type. Unilateral adrenocortical tumors are frequent in the general population; most of them are incidentally discovered on medical imaging. The prevalence of such incidentalomas ranges from 1 to $7 \%$ depending on the series and increases with ageing (Bertherat et al. 2002, Grumbach et al. 2003, Fassnacht et al. 2016). Most of them are benign adrenocortical adenomas (ACA), which can be non-secreting but can also be responsible for cortisol excess (Cushing syndrome) in $5-47 \%$ of cases and more rarely for aldosterone excess (Conn adenomas) in 1.6-3.3\% of cases (Mansmann et al. 2004, Fassnacht et al. 2016). In contrast, adrenocortical carcinomas (ACC) are rare tumors with an estimated annual incidence of $0.7-2$ cases by year and a global 
prevalence of 4-12 cases per million. Their prognosis is poor with a 5-year survival rate inferior to $35 \%$ in most series. However, prognosis varies according to tumor stage with a 5 -year survival rate of respectively $82 \%$ for stage I tumors, 58\% for stage II tumors, 52\% for stage III tumors and finally $18 \%$ for stage IV tumors (Fassnacht et al. 2009). They are responsible for steroid excess in $60-70 \%$ of cases (Mansmann et al. 2004, Kebebew et al. 2006, Kerkhofs et al. 2013). However, if clinically significant symptomatic Cushing syndrome or androgens excess can be observed, steroidogenesis is often altered in tumor cells, leading to asymptomatic steroid precursors accumulation (Arlt et al. 2011). Mineralocorticoids and estrogens excess have also been reported.

Bilateral adrenocortical tumors are less common. Two different entities can be distinguished depending on nodules size and aspect: primary bilateral macro-nodular adrenal hyperplasia (PBMAH) and bilateral micro-nodular adrenal hyperplasia (MiAH). PBMAH is defined by the presence of several nodules, whose diameter is superior to $10 \mathrm{~mm}$, and which are generally bilateral and more rarely confined to one adrenal. $\mathrm{MiAH}$ is rare and primary pigmented nodular adrenal disease (PPNAD) is its most frequent form. PPNAD is characterized by a specific macroscopic aspect of adrenals with bilateral pigmented micro-nodules widespread in adrenal cortex. PPNAD is usually diagnosed in patients with Cushing syndrome while PBMAH can cause variable degree of cortisol excess.

The molecular mechanisms of tumorigenesis are not the same in these different types of adrenal tumors. The first molecular alterations were identified by the study of rare familial tumor syndromes, including adrenocortical tumors due to an identified germline mutation or epigenetic alteration (Libé \& Bertherat 2005). Most of these alter a tumor suppressor gene. According to the Knudson model, in this context, tumors result from the clonal proliferation of a cell, in which a somatic second 'hit' has occurred on the germline wild-type allele. Alterations of these candidate genes were searched in sporadic tumors at the somatic level and allowed the identification of TP53 mutation (Li-Fraumeni syndrome) in ACC (Reincke et al. 1994), various 11p15 locus alterations leading to insulin growth factor 2 (IGF2) overexpression (Beckwith-Wiedemann syndrome) in sporadic ACC (Gicquel et al. 1997) and protein kinase A regulatory subunit 1-alpha (PRKAR1A) (Carney complex) in sporadic cortisol-secreting ACA (Bertherat et al. 2003). However, this candidate gene approach is limited and the recent development of genome-wide tools with the emergence of next-generation sequencing (NGS) has allowed at a much faster rate identification of new molecular alterations at the somatic levels in the different types of adrenal tumors.

This review aims to describe the reported molecular alterations in the different types of tumors of the adrenal cortex, a topic which has already been addressed in previous reviews (Åkerström et al. 2016, Lodish 2017). The choice was made to exclude Conn adenomas to allow a specific focus on the many recent advances made in the genomic characterization of PPNAD, PBMAH, cortisolsecreting ACA and ACC.

\section{Benign adrenocortical cortisol-producing tumors}

\section{Bilateral cortisol-producing tumors}

Bilateral adrenocortical tumors are characterized by the presence of several nodules in both adrenals and responsible for Cushing syndrome to varying degrees. Their bilateral nature suggests a possible genetic predisposition, relying on the existence of a germline mutation or epigenetic alteration. Furthermore, families with several members presenting PPNAD or PBMAH had been reported.

\section{Primary pigmented nodular adrenal disease (PPNAD)}

PPNAD, the most common form of $\mathrm{MiAH}$, is a rare cause of ACTH-independent hypercorticism, most often diagnosed in children and young adults. Its name comes from the particular macroscopic aspect of adrenals in this pathology, with pigmented micronodules (diameter inferior to $10 \mathrm{~mm}$ ) widespread in the cortex of both adrenals. PPNAD is most often observed in patients with Carney complex (CNC), a familial tumor predisposition syndrome, responsible for several types of tumor, including other endocrine lesions: somatotroph pituitary adenomas, testicular Sertoli cell-calcified tumors and thyroid benign or malignant lesions but also nonendocrine manifestations, mainly, cardiac myxomas, pigmented skin lesions (lentiginosis and naevi) and melanocytic schwannomas. The prevalence of PPNAD in patients with CNC is approximately 60\% (Stratakis 2000, Bertherat et al. 2009).

CNC is inherited in an autosomal dominant manner. Linkage studies allowed the identification of 2 different loci associated with the disease: one in the short arm of the chromosome 2 (2p16), a region including proopiomelanocortin (POMC) gene and DNAmismatch repair gene $\mathrm{MSH} 2,2$ genes further excluded 
(Stratakis et al. 1996) and the other on the long arm of chromosome 17 (17q22-24) (Casey et al. 1998). Deleterious germline mutations of PRKAR1A gene, coding for one of the regulatory subunit of PKA, were identified at the 17q22-24 locus and are responsible for more than two-thirds of Carney complex index cases, from 37\% in the sporadic forms to $80 \%$ in the typical familial forms (Bertherat et al. 2009). The first germline mutations identified led to frameshift, usually causing a premature stop codon (Kirschner et al. 2000). They were often associated with loss of heterozygosity ( $\mathrm{LOH})$, involving somatic loss of the wild-type allele in CNC tumors. Expression of PKA regulatory subunit R1A was therefore completely lost in tumor cells.

This is a clear example of alteration of the cyclic adenosine monophosphate (cAMP)/protein kinase A (PKA) pathway in endocrine tumors. Physiologically, in adrenocortical cells, adrenocorticotropic hormone (ACTH) binds to its 7-transmembrane G protein-coupled receptor $\mathrm{MC} 2 \mathrm{R}$, resulting in $\mathrm{Gs}$ protein activation, further activating adenylyl cyclase resulting in enhanced cAMP production (Fig. 1). PKA is a hetero tetramer, composed of 2 regulatory subunits and 2 catalytic subunits. The binding of 4 cAMP molecules to PKA regulatory subunits dimer, allows the release and subsequent activation of the 2 catalytic subunits, which will further phosphorylate several targets, including the transcription factor CREB (cAMP response element-binding protein), responsible for the stimulation of cAMP-dependent genes transcription. Phosphodiesterases, involved in cAMP degradation, act as negative regulators of this pathway. ACTH is known to stimulate both adrenocortical cell growth and cortisol synthesis, it is then easy to understand how constitutive activation of cAMP/PKA pathway can lead to both tumorigenesis and Cushing syndrome.

Indeed, inactivation of PRKAR1A results in constitutive activation of the cAMP/PKA pathway. PRKAR1A is considered as a potential tumor suppressor gene in tissues where tumors occur in Carney complex patients. Very few hotspot mutations were identified in the PRKAR1A gene. Reported mutations are distributed along the whole coding sequence and to a smaller extent (about 20\%) noncoding sequence, intronic mutations affecting splicing. Only 2 mutations were found with a higher prevalence in a large study, including 353 patients with CNC and/or PPNAD: the c.709-7del6 in intron 7, mostly reported in cases of isolated PPNAD and the c.491-492delTG in exon 5, significantly associated with cardiac myxoma, lentigines and thyroid tumors when compared with other PRKAR1A defects. About $80 \%$ of these mutations are subject to mRNA nonsense-mediated decay (NMD), coding for an mRNA, which is not translated into protein. The $20 \%$ of mutations, escaping $\mathrm{NMD}$, lead potentially to the expression of an alternative protein and are probably responsible for a more aggressive form of the disease, including a higher total number of CNC manifestations (Bertherat et al. 2009). A dominantnegative effect was described for at least one PRKAR1A mutation escaping NMD, an intronic base substitution in intron 6 (exon 6 IVS $+1 \mathrm{G}>\mathrm{T}$ )-inducing exon 6 skipping and expression of a shorter protein. Indeed, 5 different CNC tumors (left and right adrenal nodules, pancreatic adenocarcinoma, schwannoma and hepatoma) from a patient carrying this specific mutation were screened for LOH at PRKAR1A locus. The loss of the wild-type allele was only found in the most aggressive tumor, the pancreatic adenocarcinoma, suggesting that this event was not necessary for cell proliferation in the other tissues. The mutant R1A had necessarily a dominant-negative effect, responsible for R1A downregulation in the initial tumor stages (Groussin et al. 2002). Other mutations, leading to frameshift and creation of a new stop codon into the $3^{\prime}$ untranslated open-reading frame (3'-UTR), escape NMD and are expected to generate a longer protein. However, the resulting elongated proteins are directly addressed to proteasome and precociously degraded (Patronas et al. 2012), leading to haploinsufficiency. Mouse models confirmed the role of PRKAR1A alteration in adrenal tumorigenesis and excessive cortisol production. Indeed, mice lacking PRKAR1A specifically in the adrenal cortex (AdKO) developed pituitary-independent Cushing's syndrome with increased PKA activity. The loss of R1A in adrenocortical cells led to autonomous steroidogenic genes expression, deregulated differentiation, increased proliferation and resistance to apoptosis, mimicking the phenotype observed in human PPNAD (Sahut-Barnola et al. 2010).

Genetic alterations of other actors of the cAMP/PKA pathway were further described in patients with PPNAD. They affect in particular the genes coding for phosphodiesterases PDE11A and PDE8B, which are involved in cAMP degradation. Genome-wide singlenucleotide polymorphism (SNP) array, focusing on cAMP-related genes, compared ten tetrads of samples, each tetrad containing leucocyte DNA from the proband and its 2 parents plus adrenal tumor DNA from the proband. This allowed identification of the 2q31-2q35 locus as the largest $\mathrm{LOH}$ region in the dataset. Located in this locus, PDE11A appeared as an obvious candidate gene because of its inclusion in identified allelic losses 
A

B

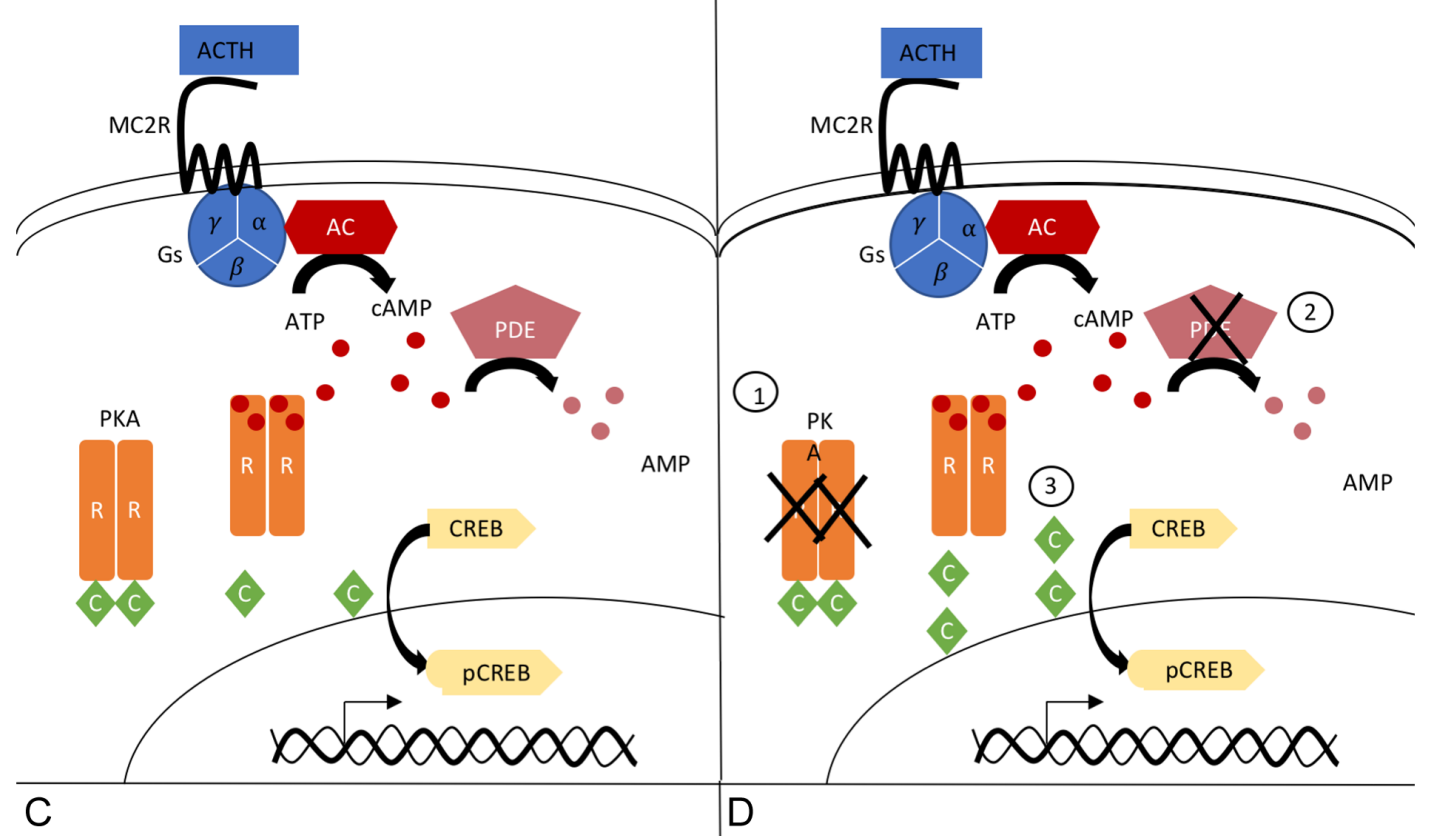

(5)

(5)
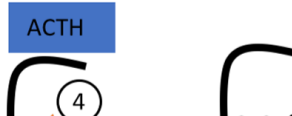

(1)

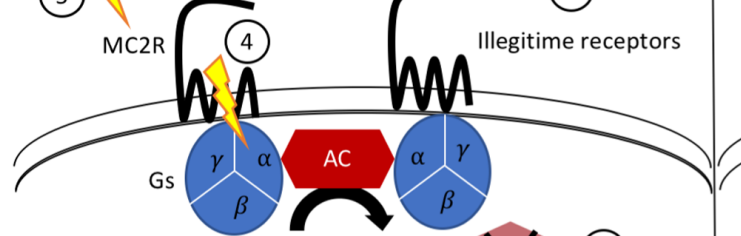

Gs

ATP CAMP

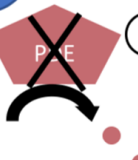

(2)

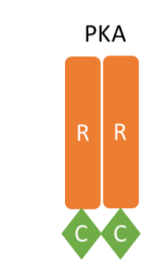

.

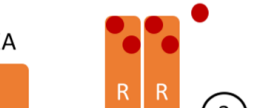

(3)

$\therefore \mathrm{AMP}$

(2)

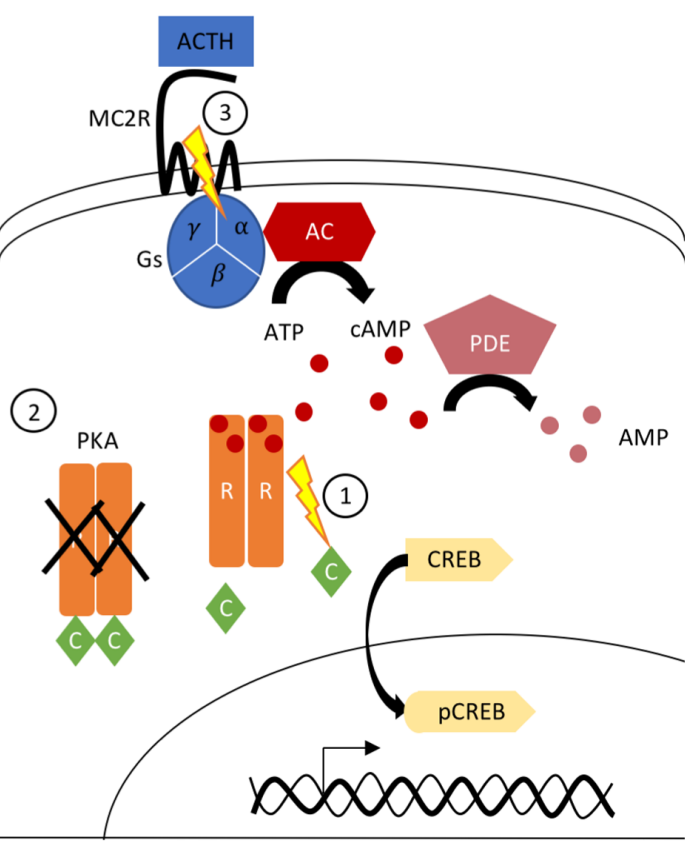

Figure 1

The CAMP/PKA signaling pathway in the adrenal cortex. (A) The CAMP/PKA signaling pathway in normal adrenocortical cell. Adrenocorticotropic hormone (ACTH) binds to its $G$ protein-coupled receptor MC2R, resulting in Gs protein activation, which further activates adenylyl cyclase (AC), resulting in enhanced cAMP production. PKA is a hetero tetramer, composed of 2 regulatory subunits (R) and 2 catalytic subunits (C). The binding of 4 cAMP molecules to PKA regulatory subunits dimer allows the release and subsequent activation of the 2 catalytic subunits. The free catalytic subunits will then phosphorylate several targets, including the transcription factor CREB (CAMP response element-binding protein), responsible for the stimulation of CAMP-dependent genes transcription. Phosphodiesterases (PDE), involved in CAMP degradation, act as negative regulators of this pathway. (B) CAMP/ PKA signaling pathway genetic alterations in PPNAD 1: PRKAR1A inactivation (germline mutation + somatic second-hit); 2: phosphodiesterases (PDE11A or PD8B) inactivation (germline mutation + tumoral LOH); 3: PRKACA duplication, PRKACB triplication (C) CAMP/PKA signaling pathway genetic alterations in PBMAH 1: Illegitimate G-protein-coupled receptors expression 2: Phosphodiesterases (PDE11A or PD8B) inactivation (germline mutation + tumoral LOH) 3: PRKACA duplication 4: Activating mutation of GNAS1 (Mac Cune Albright syndrome) 5: Activating mutation of MC2R (D) CAMP/PKA signaling pathway genetic alterations in cortisol-producing adenomas 1: Activating mutations of PRKACA (hotspot L206R) 2: PRKAR1A inactivation 3: GNAS1-activating mutation, apart from McCune-Albright syndrome context. 
and its known function and expression pattern. Three germline deleterious variants in PDE11A were indeed identified in 16 patients with isolated MiAH/PPNAD and no mutations of PRKAR1A nor other Carney complex tumors (Horvath et al. 2006). Furthermore, PDE11A could also act as a modifier gene in patients with CNC secondary to PRKAR1A mutation (Libé et al. 2011). PDE11A gene was entirely sequenced in $150 \mathrm{CNC}$ patients carrying a germline mutation of PRKAR1A, allowing the identification of single-nucleotide variations (SNV) in the heterozygous state in 38 cases (25.3\%): missense substitutions (in 31 patients) or premature stop codon and nonsense mRNA (in 7 patients). In comparison, PDE11A SNVs were only identified in 19 of 279 control subjects (6.8\%) and consisted of 4 previously reported missense variants and no nonsense mutations. Some of the variants, identified in CNC patients, were shown to have decreased enzymatic activity in vitro (Horvath et al. 2006) and could thus participate to genetic predisposition to PPNAD. Interestingly, PDE11A variants were also significantly more frequent in CNC patients with PPNAD than in those without PPNAD.

After the PDE11A locus, PDE8B locus had the second highest linkage score in the previously described genomewide association (WGA) study (Horvath et al. 2006, 2008). A single base substitution c.914A $>$ C/p.His305Pro was identified in a young girl with PPNAD, who had presented Cushing's syndrome at the age of 2 years, decreased activity of the mutant PDE8B being confirmed in vitro in HEK293 cells (Horvath et al. 2008). The functional role of PDE8B in the adrenal cortex was confirmed in mouse models, $P D E 8 B$-knockout mice exhibiting elevated urinary corticosterone as a result of adrenal hypersensitivity toward ACTH (Tsai et al. 2011).

Notably, PDE11A and PDE8B alterations were not specific of PPNAD and were further described in other types of adrenocortical tumors. Thus, a heterozygousinactivating mutation in PDE11A was found in a nonsecreting adrenocortical adenoma (Libé et al. 2008), and heterozygous missense variants were reported in PBMAH (24\%), in ACA (19\%) and in ACC (16\%), with a higher frequency than in control subjects (5.7\%). In vitro study confirmed that 2 PDE11A variants, only found in PBMAH (and not in controls) had decreased enzymatic activity in comparison to wild-type PDE11A (Vezzosi et al. 2012). It is speculated that these PDE11A variants play a role in the genetic predisposition to develop PBMAH as a secondary modifying gene and not as a 'causal' gene on its own. Concerning PDE8B, the screening of 216 adrenocortical tumors negative for mutations in PRKAR1A, PDE11A and
GNAS, identified 6 different variants of PDESB in a total 7 patients (1 ACC, 1 PPNAD, 2 PBMAH, 2 secreting ACA and 1 non-secreting ACA). The deleterious effect of the genetic alteration was confirmed for at least two of them (Rothenbuhler et al. 2012).

More recently, the catalytic subunits of the PKA enzyme were reported to be involved in MiAH. Indeed, a comparative genomic hybridization (CGH) study including 35 patients with bilateral adrenal hyperplasia and overt Cushing syndrome, with no PRKAR1A, PDE11A and PDE8B germline mutations, identified 5 patients (4 kindreds) with duplication of $19 \mathrm{p}$ region, including PRKACA. As expected, tumor samples of these patients exhibited higher expression of PRKACA at mRNA and protein level, resulting in higher basal and stimulated PKA activity. Their phenotype was quite heterogeneous, including both micro-nodular and macro-nodular forms and various degrees of Cushing syndrome severity (Beuschlein et al. 2014). Recently, a $1.6 \mathrm{Mb}$ triplication of 1 p31.1 chromosome region, including PRKACB gene, was found in a genome-wide study in a young woman with Carney complex who did not carry either PRKAR1A or PRKACA mutation (Forlino et al. 2014). Her Carney complex manifestations associated acromegaly, pigmented spots and myxomas but no PPNAD.

\section{Primary bilateral macronodular adrenal hyperplasia (PBMAH)}

PBMAH is typically characterized by the presence of several bilateral adrenal macro-nodules (diameter superior to $10 \mathrm{~mm}$ ). More rarely, PBMAH can also be asymmetric and in some case apparently unilateral. Diagnosis is made in patients, between 40 and 65 years of age, presenting with Cushing syndrome and low plasma ACTH levels or often nowadays after the investigation of an adrenal incidentaloma. This pathology is slightly more prevalent in women. The severity of Cushing syndrome is extremely variable and can even be completely asymptomatic. PBMAH has long been referred to as 'ACTH-independent macronodular adrenal hyperplasia' (AIMAH), but the recent discovery of an intraadrenal ACTH synthesis responsible for local stimulation of cortisol production made the former appellation obsolete. This ectopic ACTH is secreted by adrenocortical cells, localized in the subcapsular region and in hyperplasic nodules which express both pro-convertase 1 (PC1), the ACTH-precursor clivage enzyme, and usual enzymatic resources of cells capable of steroidogenesis. The regulation of this ectopic ACTH is very different from that of pituitary ACTH (Louiset et al. 2013). The great originality in PBMAH resides in 
the cortisol response to non-physiological stimuli, giving birth to the concept of illegitimate membrane receptors in adrenocortical cells. Various stimulating ligands, binding to protein G-coupled receptors were described, including glucose-dependent insulinotropic peptide (GIP) responsible for food-dependent Cushing syndrome (Reznik et al. 1992), LH/HCG responsible for Cushing syndrome during pregnancy and after menopause (Lacroix et al. 1999), vasopressin, catecholamines, serotonin 5-HT, angiotensin II (ang II) and glucagon (Imöhl et al. 2002, Miyamura et al. 2002, Lee et al. 2005, Vezzosi et al. 2007, Gagliardi et al. 2009, Libé et al. 2010, Hofland et al. 2013). The prevalence of such illegitimate membrane receptors in PBMAH is high, varying from $77 \%$ to $87 \%$ among studies (Libé et al. 2010, Hofland et al. 2013). However, despite whole-genome approaches (Lampron et al. 2006), genetic alterations responsible for this ectopic expression have not been elucidated yet. Adrenal tumorigenesis and excessive cortisol secretion are again secondary to cAMP/PKA pathway activation in the context of PBMAH, most of these illegitimate $G$ protein-coupled receptors stimulating adenylyl cyclase.

Genetic alterations of other actors of cAMP/PKA pathway were also reported in PBMAH. As described in the previous section, PDE11A variants were found with a prevalence of $24-28 \%$ in PBMAH patients (Libé et al. 2008, Vezzosi et al. 2012), some of them being associated with decreased enzymatic activity confirmed in vitro (Vezzosi et al. 2012). Hypersensitivity to ACTH, secondary to mutations of ACTH receptor $M C 2 R$, was also described in an isolated case of bilateral adrenal hyperplasia. In this particular case, the association of 2 mutations (responsible for loss of ligand binding and responsiveness) on the same allele of $M C 2 R$ resulted in significant elevation in its constitutive activity and subsequent autonomous cortisol secretion (Swords et al. 2004). The last actor of cAMP/PKA pathway involved in PBMAH is the alphasubunit of Gs protein (encoded by GNAS1 gene) in the context of McCune-Albright syndrome (Fragoso et al. 2003). This syndrome associates polyostotic fibrous dysplasia, 'café au lait' spots, precocious puberty and hyperfunction of multiple endocrine glands. Somatic activating mutations of GNAS1 occur early in embryogenesis, giving birth to a mosaic population of wild-type and mutant gene-bearing tissues, underlying the clinical manifestations. Again, these activating mutations result in constitutive activation of cAMP/PKA pathway and autonomous cortisol secretion (Weinstein et al. 1991).

Few rare cases of PBMAH are part of other genetic tumors predisposition syndrome including multiple endocrine neoplasia type 1 (MEN1), familial adenomatous polyposis (APC) and hereditary leiomyomatosis (fumarate hydrogenase, FH) (Matyakhina et al. 2005, Hsiao et al. 2009, Gatta-Cherifi et al. 2012, Shuch et al. 2013). However, these particular alterations only explain a very small proportion of PBMAH cases and are by nature associated with other tumors.

Genome-wide approaches allowed considerable progress in understanding PBMAH pathogenesis with the recent identification of a new tumor suppressor gene involved in this disease. Blood and tumor DNA samples were collected from 33 patients with PBMAH, who had undergone adrenal surgery for Cushing's syndrome and/or very large adrenal (Assié et al. 2013). LOH was detected at 16p locus by SNP array in the tumors of $8 / 33$ patients (24\%). Whole-genome sequencing in 5 paired tumor and leucocyte DNA samples identified only one gene affected in more than one tumor sample, ARMC5, mapping to $16 \mathrm{p} 11.2$. Direct sequencing of tumor DNA further identified ARMC5 mutations in a total of 18/33 patients. All tumor DNA samples of these 18 patients harbored 2 genetic alterations in ARMC5 locus, whereas their leucocyte DNA samples carried only one of the 2 alterations identified in the tumor, confirming the role of ARMC5 as a tumor suppressor gene in PBMAH. Interestingly, tumor DNA was sequenced in more than one tumor in a few patients. In each case, the germline ARMC5 mutation was associated with a second nodulespecific, somatic ARMC5 alteration (Assié et al. 2013). This extensive genetic variance in the second event leading to tumorigenesis was confirmed by the analysis of 20 adrenal nodules from one patient with PBMAH. In addition to what appeared to be the germline mutation p.Trp476*, sixteen of the 20 nodules harbored a second somatic $A R M C 5$ variant, each of them being unique and specific to one nodule. Allelic losses were identified in two of them (Correa et al. 2015).

The prevalence of ARMC5 damaging germline mutations in PBMAH was further estimated from $21 \%$ to $26 \%$ in the following studies (Faucz et al. 2014, Espiard et al. 2015). The majority of index case patients carrying ARMC5 deleterious mutations had clear adrenal Cushing syndrome. Cortisol hypersecretion in this subgroup was more severe in comparison to index case patients without ARMC5 mutation or with ARMC5 variant predicted to be benign. This difference had an anatomical substratum, adrenals in patients carrying ARMC5 deleterious mutation were indeed larger and harbored a higher number of nodules (Espiard et al. 2015, Albiger et al. 2017). An ARMC5-damaging mutation or deletion was found to 
segregate in several families of PBMAH (Suzuki et al. 2015, Bourdeau et al. 2016). Interestingly, adrenal hyperplasia was associated with meningioma in one family carrying (p. A110fs*9) ARMC5 mutation (Elbelt et al. 2015). A second 'hit' on ARMC5 gene was found in the meningioma DNA, suggesting an additional role of ARMC5 in the predisposition to meningiomas. Expression of the four known ARMC5 isoforms was recently investigated in 46 normal human tissues (Berthon et al. 2017a): only one isoform was ubiquitously expressed throughout the body, whereas only 7 tissues expressed the four isoforms, including adrenals and brain.

ARMC5 is a cytosolic protein with no enzymatic activity, containing 7 armadillo domains and one BTB domain toward its C-terminus, which allows its di- or trimerization (Hu et al. 2017). More than 240 proteins from yeast to human are known to contain armadillo domains, including the well-known beta-catenin. Armadillo-containing proteins are involved in many different functions, including T-cell, neural tube and adrenal cortex development as well as tumor suppression. First functional investigations showed that inactivation of ARMC5 in H295R cells by siRNA led to a decrease in expression of steroidogenesis enzymes and in cortisol synthesis. Furthermore, ARMC5 missense mutations or deletions were not able to induce apoptosis in H295R and HeLa cells in the contrary of wild-type ARMC5 (Assié et al. 2013, Espiard et al. 2015). Despite the reduced capacity of each cell, excess in cortisol secretion in PBMAH could therefore result from the increased number of adrenocortical cells, underlying the insidious installation of Cushing syndrome (Assié et al. 2013). Recently, an $A R M C 5-\mathrm{KO}$ mouse model was developed to investigate ARMC5 function. ARMC5-KO was first associated with a high embryonic lethality and growth retardation. In old age ( $>15$ months), ARMC5-KO mice presented enlarged adrenals (without any identifiable nodule) and increased glucocorticoids serum level (Berthon et al. 2017b, Hu et al. 2017). These animals were immunodeficient, with altered T-cell proliferation and differentiation into Th1 and Th17 cells and increased T-cell apoptosis. ARMC5binding partners were further investigated by yeast-2hybrid assay, and identified actors in pathways regulating both cell cycling (for example, CUL3) and apoptosis (for example, DAPK1) as well as ARMC5 itself, suggesting multimerization (Hu et al. 2017).

Finally, other possible driver genes of PBMAH were reported in a small number of cases. Thus, whole exome sequencing (WES) in 7 patients with PBMAH allowed the identification of DOT1L and HDAC9 mutations in respectively 2 patients and 1 patient. DOT1L codes for a histone $\mathrm{H} 3$ lysine methyl-transferase and HDAC9 for a histone deacetylase, both being involved in histone modifications, chromatin organization and therefore gene transcription regulation (Cao et al. 2014). A single study reported a single mutation in Endothelin Receptor type A EDNRA gene, but this has not been confirmed in any other sequencing studies of large series of patients with adrenal hyperplasia. EDNRA belongs to G proteincoupled proteins and was also reported to play a role in cardiovascular and polycystic kidney disease (Zhu et al. 2013). The frequency of the alterations of these genes has not been investigated in large series.

\section{Unilateral cortisol-producing adenomas}

As for germline genetic alterations identified in bilateral adrenal tumors, somatic alterations of actors of the cAMP/PKA pathway were found in sporadic cortisolsecreting adenomas.

The most prevalent defect alters the PKA catalytic alpha-subunit (PRKACA). WES (Beuschlein et al. 2014) allowed the identification of somatic PRKACA mutations in 8 of 10 patients with cortisol-producing adenomas, the same hotspot mutation (c.617A $>$ C/p.Lys206Arg) being reported in seven patients. Twenty-two PRKACA mutations were further identified in a total of 59 ACA with overt Cushing syndrome, no mutations being found either in patients with subclinical Cushing syndrome or with other adrenal tumors. Clinical phenotype was more severe in patients whose tumor carried PRKACA mutation. The hotspot mutation (c.617A $>$ C/p.Lys206Arg) was further confirmed in four following studies (Cao et al. 2014, Di Dalmazi et al. 2014, Goh et al. 2014, Sato et al. 2014 ) with a prevalence ranging from 28 to $50 \%$. This mutation is located within the active site-cleft of the PKA catalytic subunit to which the inhibitory domain of the regulatory PKA subunit binds, mimicking a substrate for the catalytic subunit. Lysine substitution by an arginine in this position prevents PRKACA binding to PKA regulatory subunit 1 alpha, increasing basal PKA activity, further promoting PKA substrate phosphorylation and target genes expression (Beuschlein et al. 2014, Calebiro et al. 2014, Cao et al. 2014). Apart from this specific site, some rare other mutations, leading to activation of PRKACA have been reported, including c.595_596insCAC/p. Leu199_Cys200insTrp (Beuschlein et al. 2014), c.639 C>G+c.638_640insATTATCCTGAGG/p.Ser213Arg+p. 
Leu212_Lys214insIle-Ile-Leu-Arg (Di Dalmazi et al. 2014), c.589A>G/p.Trp197Arg and c.731_745del/p.245_248.del (Ronchi et al. 2016), all found respectively in one patient and c.600_601insGTG/p.Cys200_Gly201insVal reported in three patients (Di Dalmazi et al. 2014). All these alterations occurred in a region of PRKACA affecting its interaction with regulatory subunit 1 alpha (Di Dalmazi et al. 2014, Ronchi et al. 2016).

Besides, somatic alterations of PRKAR1A were also identified in sporadic adrenocortical tumors. LOH in PRKAR1A locus $17 \mathrm{q}$ was found in 7 of 29 adenomas. Three different damaging mutations were further found in 3 other adenomas, all subject to nonsense mRNA decay and therefore undetectable on the protein level (Bertherat et al. 2003). Interestingly, the three adenomas carrying these mutations were responsible for an overt Cushing syndrome and appeared pigmented on pathological examination. Moreover, they shared additional clinical features with PPNAD, including cyclic hypercortisolism, paradoxical increase in cortisol secretion during dexamethasone administration and small adenoma size (Bertherat et al. 2003). Another case of PRKAR1A mutation was further described in a WES study, including a total of 39 cortisol-producing adenomas (Cao et al. 2014). The exact prevalence of PRKAR1A somatic alteration in sporadic cortisolproducing adenomas is yet difficult to estimate, given the small number of cases reported in the different series but is probably below $5 \%$.

Finally, apart from McCune-Albright syndrome, somatic-activating mutations of GNAS1, the gene coding for Gs protein alpha-subunit, were also reported in few cases of ACA (Kobayashi et al. 2000, Libé \& Bertherat 2005, Goh et al. 2014, Ronchi et al. 2016) with an exact prevalence also difficult to estimate, ranging from 4.5 to $11 \%$.

Even if all these alterations affect cAMP/PKA pathway, they seem to activate different downstream signaling pathways. Thus, in a whole genome expression profile study, comparing normal adrenal tissue to 3 GNAS-mutant tumors and 3 PRKAR1A-mutant tumors, both types of tumors shared overexpression of MAPK and p53 signaling pathways in comparison to normal tissue but differed substantially on others. Indeed, extracellular matrix receptor interaction and focal adhesion pathways (involving NFKB, NFKBIA and TNFRSF1A genes) were overexpressed in GNAS-mutant tumors while genes related to Wnt signaling pathway (CCND1, CTNNB1, LEF1, LRP5, WISP1 and WNT3) were higher in PRKAR1A-mutant tumors (Almeida et al. 2012).

\section{Wnt/beta-catenin signaling pathway activation in benign cortisol-producing tumors}

Familial adenomatous polyposis (FAP) is a model of activation of Wnt/beta-catenin in oncogenesis and is characterized by the development of tens to thousands of adenomas in the rectum and colon during the second decade of life, leading to colorectal cancer development generally one decade after the appearance of the polyps. FAP may present with some extraintestinal manifestations such as osteomas, dental abnormalities (unerupted teeth, congenital absence of one or more teeth, supernumerary teeth, dentigerous cysts and odontomas), congenital hypertrophy of the retinal pigment epithelium (CHRPE), desmoid tumors and extracolonic cancers (thyroid, liver, bile ducts and central nervous system). A less-aggressive variant of FAP, Gardner syndrome, is characterized by fewer colorectal adenomatous polyps, later age of adenoma appearance and lower cancer risk. Classic FAP is inherited in an autosomal dominant manner and results from a germline mutation in the adenomatous polyposis (APC) gene (Half et al. 2009), encoding APC protein, which belongs to beta-catenin degradation complex, therefore acting as a negative regulator of Wnt/beta-catenin signaling pathway. More than 50 cases of adrenocortical tumor (ACT) in FAP have been reported, many of them being asymptomatic and discovered at autopsy (Beuschlein et al. 2000, Berthon et al. 2012). In retrospective studies, occurrence of adrenocortical tumors was significantly increased in FAP patients (7-13\%) (Marchesa et al. 1997) in comparison to non-FAP patients, although it should be kept in mind that these values might be overestimated because of increased imaging prescription in FAP. All ACT tumors in FAP patients harbored biallelic inactivation of $A P C$, in favor of both germline and somatic mutations according to Knudson's two-hit model, leading to inappropriate cytoplasmic and/or nuclear accumulation of beta-catenin (Gaujoux et al. 2010).

Activation of the Wnt/beta-catenin pathway in sporadic adrenocortical tumors was from the initial study by our group in 2005 not only reported in ACC but also in ACA (Tissier et al. 2005). Later, in a study including 9 PPNADs (5 with macro nodules), 3 sporadic cortisolsecreting ACA with PRKAR1A somatic mutation and 1 heterogeneous tumor with an ACC developing within an ACA, beta-catenin accumulation was found in all tumor types. Furthermore, somatic mutations in CTNNB1, the gene coding for beta-catenin were identified in 2 of the 5 macronodular PPNAD, 1 ACA and in the malignant 
part of the last heterogeneous tumor. These mutations seemed to be associated with a more aggressive phenotype (Gaujoux et al. 2008). This result was confirmed in another study, which reported 2 somatic CTNNB1 mutations in 18 patients with PPNAD (Tadjine et al. 2008), these mutations were again associated with larger nodules. Betacatenin accumulation might also be caused by cAMP/PKA pathway activation. GSK3-beta, phosphorylated by PKA on Ser 9, is unable to participate in Axin-APC complex and to phosphorylate beta-catenin. Beta-catenin thus escapes degradation and accumulates in both nuclear and cytoplasmic compartments. Besides, beta-catenin by itself can be directly phosphorylated by PKA on Ser 675 , inhibiting its degradation or promoting its binding to its transcriptional coactivator cAMP response elementbinding protein (CREB) (Gaujoux et al. 2008, Berthon et al. 2012). Beta-catenin accumulation was also found in 10 of 26 ACA without specific somatic mutation of PRKAR1A. Seven of them harbored a somatic mutation in CTNNB1. Most of these mutations affected Ser 45 in the exon 3 of CTNNB1, in the consensus GSK3-beta phosphorylation site and led to subsequent activation of T-cell factordependent transcription in functional studies (Tissier et al. 2005). Interestingly, in a large study including 100 ACA, beta-catenin mutations were more frequent in nonsecreting ACA (61\%) than in subclinical cortisol-secreting ACA (22\%) and cortisol-secreting ACA (16\%). Mutated tumors were also significantly larger than non-mutated lesions (Bonnet et al. 2011).

\section{Adrenocortical carcinomas (ACC)}

ACC is a rare tumor with a poor prognosis, which can be diagnosed by the investigation of endocrine signs of steroid excess, compression symptoms due to tumor growth or simply on adrenal incidentaloma. Most tumors demonstrate steroid over secretion, often associating glucocorticoids and androgens. Despite an overall low 5 -year survival rate (below 30\% in most series), some tumors will not show recurrence after surgical removal and others will have a relatively slow metastatic progression. This heterogeneity long remained not understood. However, the recent discovery of genetic alterations underlying ACC tumorigenesis led to the identification of ACC molecular subgroups and molecular prognostic factors, underlying the clinical outcome heterogeneity. As in benign adrenocortical tumors, germline mutations responsible for familial syndromes predisposing to ACC, allowed the identification of signaling pathways involved in cancer development, somatic alterations of these pathways being further screened in sporadic cases of ACC (Libè et al. 2007, Espiard \& Bertherat 2015).

\section{Signaling pathways involved in adrenal malignant carcinogenesis}

\section{p53 signaling pathway}

Li-Fraumeni syndrome (LFS) is a rare autosomal dominant cancer predisposition syndrome, including soft tissue sarcoma and osteosarcoma, breast cancer, brain cancer, leukemia and ACC (Malkin et al. 1990, Bougeard et al. 2008, Mai et al. 2016). Clinical diagnostic criteria for the 'classic' LFS include an individual with sarcoma diagnosed before 45 years of age, with a first-degree relative with any cancer diagnosed before 45 years of age and another firstdegree or second-degree relative with a sarcoma diagnosed at any age or any cancer diagnosed before 45 years of age. Less stringent criteria were further established to define Li-Fraumeni-like (LFL) syndrome, the proband's cancer type being extended to childhood cancers, namely brain cancers and ACC and the relatives' age at the time of diagnosis to $<60$ years. Germline mutations in TP53, the underlying molecular basis of LFS, were identified in $70 \%$ of 'classic LFS' families and 40\% of LFL families. De novo mutations of TP53 are not rare with a prevalence ranging from 7 to 20\% among studies (Wasserman et al. 2012, Mai et al. 2016). In the National Cancer Institute's Li Fraumeni Study cohort, including 286 TP53+ individuals from 107 families, the cumulative cancer incidence was $50 \%$ by the age of 31 years among females and by the age of 46 years among males (Mai et al. 2016). One hundred and ninety-three patients (67\%) of the cohort had a first cancer diagnosis. Interestingly, ACC was the first cancer in 5 cases, diagnosis being always made before the age of 17 years. Among these 193 patients, 50\% developed a second cancer, which was an ACC in only one case (Mai et al. 2016). Prevalence of TP53 germline mutations is very different between pediatric and adult ACC. The first pediatric series of ACC were biased by the geographic origin of included patients. Indeed, the incidence of pediatric ACC is remarkably high (10-15 times the world-wide occurrence) in Southern Brazil because of the segregation of the TP53 hotspot mutation p.R337H. In this region, $90 \%$ of pediatric ACC cases harbor this mutation. A free screening of 171,649 newborns in the state of Parana identified the mutation with a prevalence of $0.27 \%$ (Faria \& Almeida 2012, Custódio et al. 2013). A recent study including 88 unrelated children with ACC who were not specifically originating from Southern Brazil, reported $50 \%$ of TP53 germline mutations, this high prevalence 
TP53 mutations' prevalence in a large cohort of adults ACC

declined with age (Wasserman et al. 2015). Indeed, TP53 germline mutations are far less frequent in the context of adult ACC, ranging from 3.9 to $5.8 \%$ among studies (Espiard \& Bertherat 2015). Furthermore, some TP53 SNPs seem to be associated with the risk of ACC development (3 of 4 SNPs tested were significantly different between control subjects and patients with ACC) and the overall survival (patients harboring at least one SNP among the four tested had a poorer prognosis) (Heinze et al. 2014) (Fig. 2).

TP53 alterations were also identified in ACC at the somatic level. The protein p53 is known as the 'guardian of genome' and is involved in cellular response to stress. In normal conditions, p53 is degraded by an E3 ubiquitin ligase $\mathrm{mdm} 2$. Under stress conditions, the association between $\mathrm{p} 53$ and $\mathrm{mdm} 2$ is abolished, leading to an increase in intracellular p53. p53 then undergoes subsequent modifications allowing its activation as a transcriptional factor, leading to the transcription of many genes. This process can have two different results: cellular division stop, DNA reparation or resolution of other abnormalities and cellular division recovery or apoptosis according to the severity of the alterations. Its gene is located at the 17 p13 locus. $\mathrm{LOH}$ at this locus are very frequent (85\%) in adult sporadic ACC (Gicquel et al. 2001). However, TP53 mutations and intragenic LOH were only found in respectively, $33 \%$ and $44 \%$ of tumors with $\mathrm{LOH}$ at the 17 p13 locus, suggesting that TP53 might not be the only tumor suppressor gene at this locus (Libè et al. 2007). ranged between 16 and 21\% in two recent genome-wide studies (Assié et al. 2014, Zheng et al. 2016). TP53-mutant tumors often exhibit a strong nuclear immunoreactivity, which can be used as a diagnostic tool. Their phenotype is more severe than non-mutant tumors with larger tumors, more advanced stage of tumor progression and shorter disease-free survival (Libè et al. 2007).

Alterations of other actors of the p53 signaling pathway were also been reported. Overexpression of PTTG1, encoding a securin, a negative regulator of TP53 was reported in $84 \%$ of ACC and appeared to be a marker of poor survival (Demeure et al. 2013). Loss of the retinoblastoma protein $\mathrm{pRb}$ in immunochemistry, secondary to deleterious mutation or allelic loss was found in $27 \%$ of ACC, all these tumors being aggressive (Ragazzon et al. 2014). Mutations of RB1 were identified in 7\% of ACC in two different large cohorts (Assié et al. 2014, Zheng et al. 2016). Additional inactivating mutations or homozygous deletions of $C D K N 2 A$ were found in 11-16\% of ACC, while high-level amplifications of CDK4 and MDM2 were both reported in $2-7 \%$ of cases, leading to an alteration of p53 signaling pathway in 33-45\% of ACC (Assié et al. 2014, Zheng et al. 2016).

\section{Wnt/beta-catenin signaling pathway}

As previously described, beta-catenin activation is observed in ACA. However, as determined by
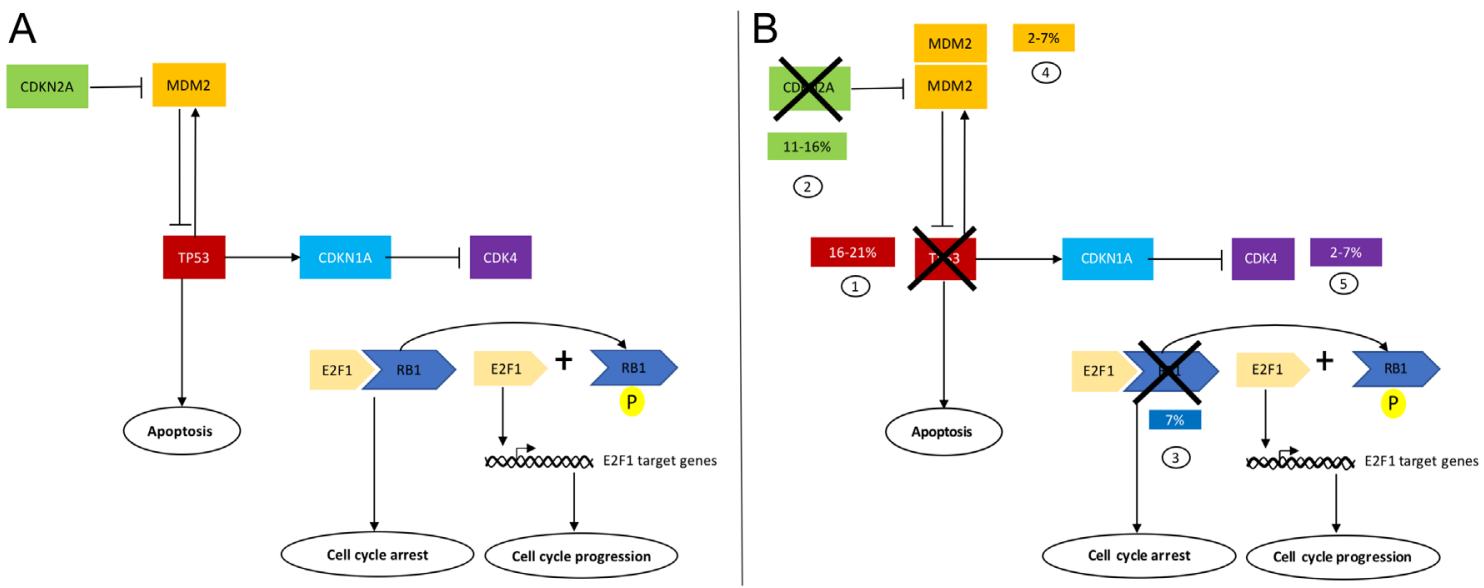

Figure 2

p53 signaling pathway. (A) p53 signaling pathway in physiology. In normal conditions, p53 is degraded by an E3 ubiquitin ligase mdm2. Under stress conditions, the association between $\mathrm{p} 53$ and $\mathrm{mdm} 2$ is abolished, leading to $\mathrm{p} 53$ activation as a transcriptional factor. This process can have two different results: cell cycle arrest or apoptosis. Cell cycle arrest involves p21 (encoded by CDKN1A) activation by p53, leading to cdk4 inhibition. Cdk4 usually inactivates Rb by phosphorylation, liberating E2F, acting as a transcription factor for target genes involved in cell cycle progression. CDKN2A codes for different proteins including ARF, which prevents $\mathrm{p} 53$ degradation by $\mathrm{mdm} 2$. (B) Genetic alterations of p53 signaling pathway in ACC. 1: Inactivating mutations of TP53; 2: Inactivating mutations of CDKN2A; 3: Inactivating mutations of RB1; 4: High-level amplification of MDM2 and 5: High-level amplification of CDK4. 
mutation of beta-catenin, and no correlation was found

immunohistochemistry, it is more dramatic in ACC in which inappropriate cytoplasmic and/or nuclear accumulation of beta-catenin is very frequent with a reported prevalence between 39\% and 84\% (Tissier et al. 2005, Gaujoux et al. 2010). Somatic mutations in APC are rare with a reported prevalence of 2-3\% (Assié et al. 2014, Zheng et al. 2016), suggesting the importance of somatic alteration of other actors of the Wnt/beta-catenin pathway in ACC. Indeed, activating somatic mutations of betacatenin itself were reported with a prevalence of about 16\% in large cohorts of ACC (Gaujoux et al. 2011, Assié et al. 2014, Zheng et al. 2016). Screening of others genes coding for proteins involved in the multiprotein complex leading to beta-catenin degradation (WTX, AXIN2, AXIN1) did not identify any deleterious mutations in these genes (Gaujoux et al. 2011, Guimier et al. 2013). Indeed, a 12pbin frame deletion in exon 7 of AXIN2 was reported in one of the 6 ACC (Chapman et al. 2011) and was associated with cytoplasmic/nuclear beta-catenin accumulation, but the tumor also harbored an activating mutation of betacatenin. This deletion was further found in only one of 49 ACC (Guimier et al. 2013), and in the cell lines H295 and H295R. It was always associated with an activating between AXIN2 expression level and nuclear beta-catenin staining, making a functional consequence of this deletion unlikely. Transcriptome studies have shown that Wnt/beta-catenin target genes, including BIRC5, ENC1, PTTG1 and TWIST1, were overexpressed in ACC. Moreover, beta-catenin alterations segregate in a subgroup of aggressive ACC, also identified by transcriptome-based classification. Positive transcriptional target genes such as CLDN1, AXIN2 and LGR5 were also overexpressed in this aggressive subgroup (Assie et al. 2012). Taken together, these results suggest that $\mathrm{Wnt} /$ beta-catenin activation is a driver of molecular alteration in a subgroup of ACC. Interestingly, p53 and beta-catenin mutations in the aggressive subgroup are almost mutually exclusive (Ragazzon et al. 2010, Assie et al. 2012, Assié et al. 2014, Zheng et al. 2016). The role of the Wnt/beta-catenin pathway in adrenal tumorigenesis is supported by mouse models. Constitutive activation of beta-catenin in the adrenal cortex of transgenic mice resulted in progressive steroidogenic and undifferentiated spindle-shaped cells hyperplasia, which could lead to macroscopic adenomas development. Malignant characteristics such

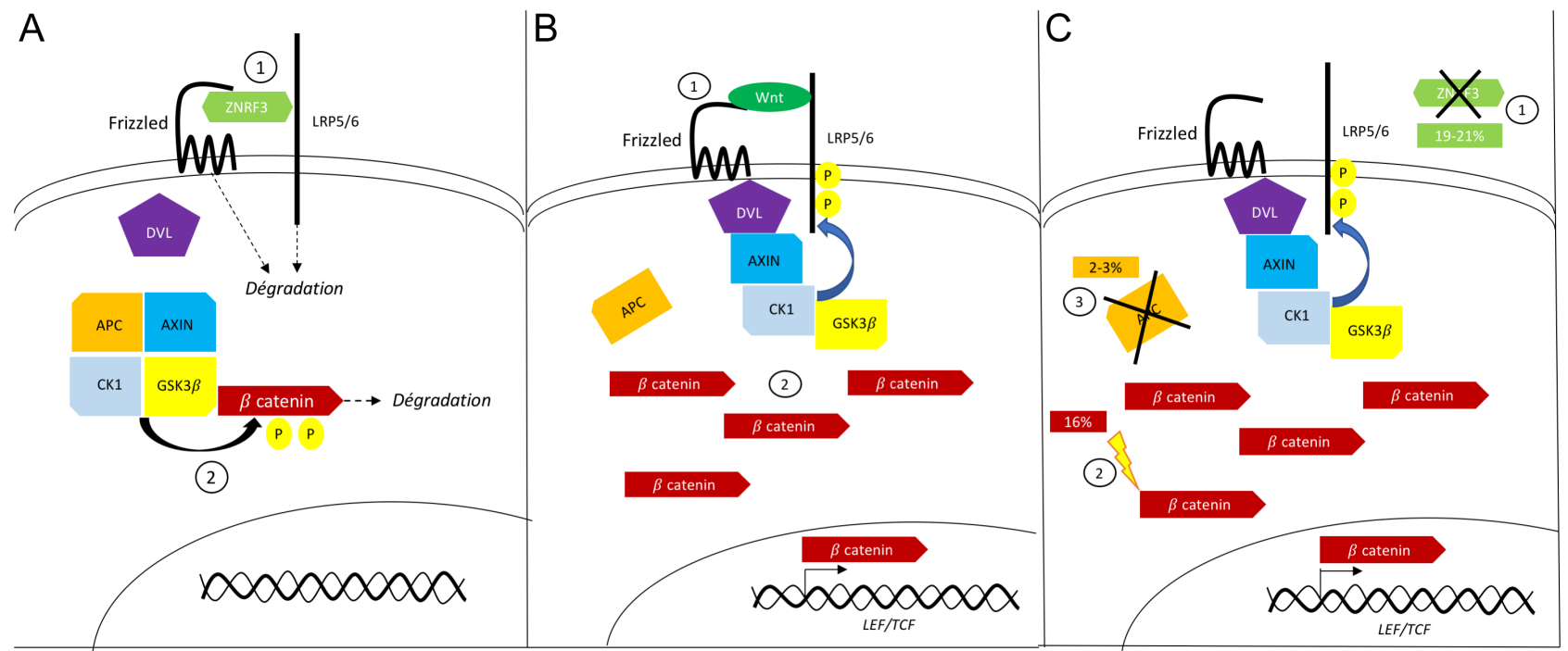

\section{Figure 3}

Wnt/ $\beta$-catenin signaling pathway (A) Regulation of Wnt/ $\beta$-catenin signaling pathway (in the absence of Wingless Wnt ligand). 1 : ZNRF3 acts as a negative regulator of Wnt/ $\beta$-catenin signaling pathway. It prevents complex formation between Wnt receptor Frizzled and its coreceptor low-density lipoprotein LRP5/6, leading to their internalization und further degradation. 2: In the absence of Wnt ligand, $\beta$-catenin is segregated in the cytoplasm, phosphorylated by GS $3 \beta$, which belongs to the degradation complex of scaffolding proteins, including also APC, AXIN and CK1, and finally targeted by an E3-ubiquitin ligase before proteosomal degradation. (B) Physiological activation of Wnt/ $\beta$-catenin signaling pathway (in the presence of Wnt ligand). 1: Wnt ligand binding to its Frizzled-LRP5/6 receptors dimer, leads to disheveled (DVL) protein recruitment and disruption of the degradation complex. 2: In the absence of functional degradation complex, the active form of $\beta$-catenin accumulates in the cytoplasm and translocates to the nucleus where it can play its role of transcriptional regulator, activating particularly the transcription of LEF/TCF transcription factor, which will further stimulate the transcription of target genes. (C) Pathological activation of Wnt/ $\beta$-catenin signaling pathway in adrenocortical carcinoma (ACC) Wnt/ $\beta$-catenin signaling pathway can be altered at different levels in ACC with: 1: Inactivating mutation of ZNRF3 in 19-21\% of cases; 2 : Activating mutation of CTNNB1 in 16\% of cases; 3 : Inactivating mutation of $A P C$ in $2-3 \%$ of cases. 

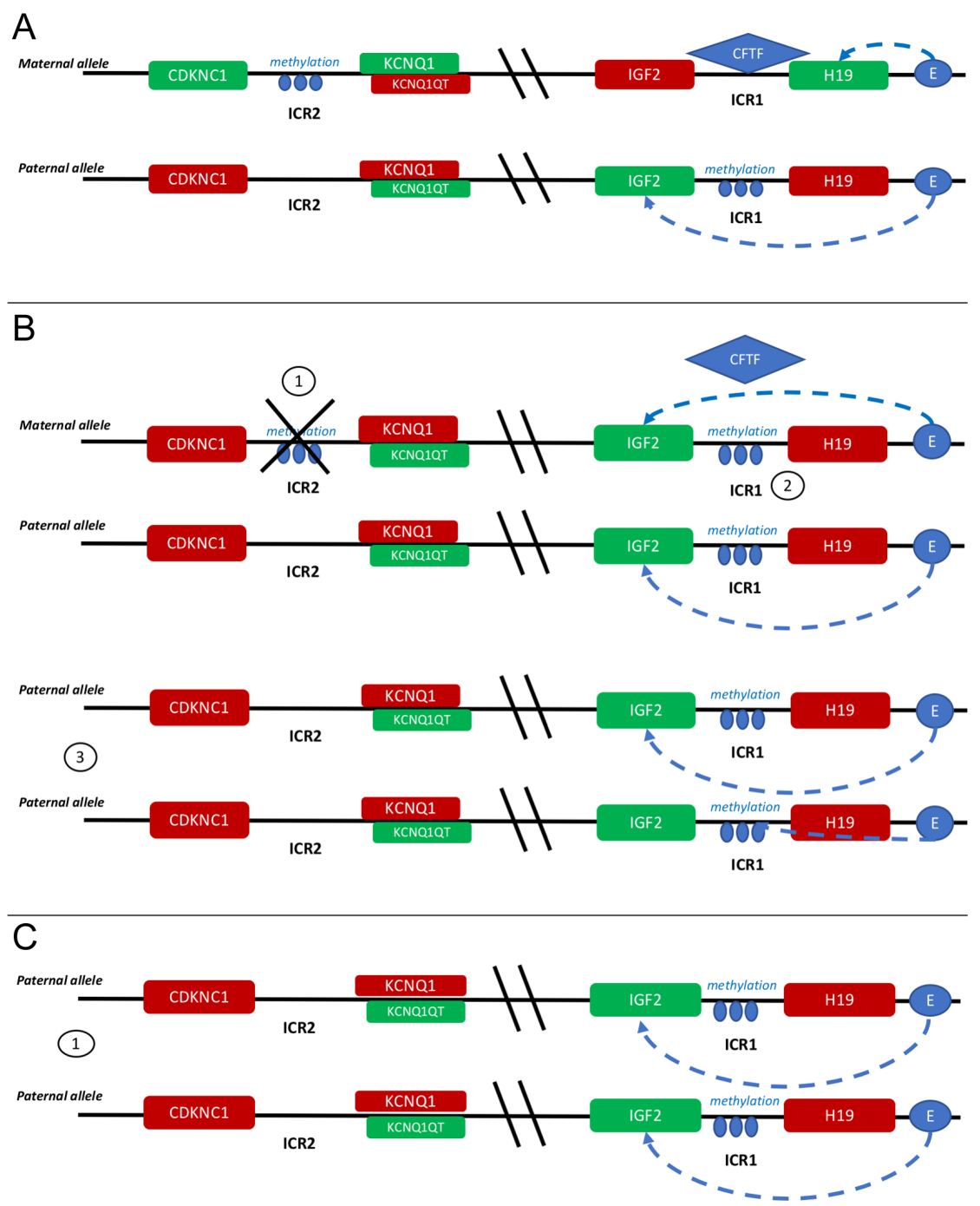

$11 \mathrm{p} 15$ locus. (A) IGF-II and the $11 \mathrm{p} 15$ locus in physiology. The $11 \mathrm{p} 15$ locus includes 2 imprinted regions ICR1 and ICR2, inversely methylated on maternal and paternal allele. On the maternal allele, the absence of methylation on ICR1 allows CFTF binding on a sequence located between IGF-II and $H 19$ genes, and further acting like an insulator. Thus, the enhancer $(E)$ is only able to activate the transcription of $\mathrm{H} 19$ and not that of IGF-II. On the contrary, on the paternal allele, the methylation of this specific sequence prevents CFTF binding, allowing the enhancer (E) to activate IGF-I/ transcription while repressing that of $H 1$. Methylation pattern is the opposite on ICRII, with methylation of the maternal allele and no methylation on the paternal one. This results in opposite expression of CDKNC1 and KCNQ1 (only expressed from the maternal allele) and $K C N Q 1 Q T$ (only expressed from the paternal allele). Expressed genes are represented in red and silent genes in green. (B) $11 \mathrm{p} 15$ locus in Beckwith-Wiedemann syndrome (BWS): 1: Loss of maternal methylation on ICR2. 2: Gain of methylation on maternal ICR1. 3: Paternal isodisomy Expressed genes are represented in red and silent genes in green. (C) $11 \mathrm{p} 15$ locus in adrenocortical carcinoma (ACC):1: High-IGF-II ACC: Paternal isodisomy 2: Low-IGF-II ACC: Paternal isodisomy and possible loss of methylation on ICR1 Expressed genes are represented in red and silent genes in green.

as uncontrolled neovascularization and loco-regional metastatic invasion appeared only lately in this context, suggesting the necessity of other associated genetic alterations (Berthon et al. 2010, Heaton et al. 2012) (Fig. 3).

More recently, a new actor of the Wnt/betacatenin pathway involved in adrenal tumorigenesis was identified. ZNRF3 encodes a cell-surface transmembrane E3 ubiquitin ligase and acts as a negative feedback regulator of Wnt signaling. ZNRF3 is associated with the Wnt receptor complex and inhibits Wnt signaling pathway by promoting the turnover of frizzled and LRP6. It is regulated by R-spondin protein that promotes the association of ZNRF3 with leucine-rich repeatcontaining $\mathrm{G}$ protein-coupled receptors LGR4, resulting in membrane clearance of ZNRF3 and activation of Wnt/beta-catenin pathway. Recently, ZNRF3 was found to be the most frequently altered gene in 2 large cohorts of ACC investigated by integrated genomics, with a prevalence of respectively 21\% (Assié et al. 2014) and 19\% (Zheng et al. 2016). These alterations consisted of biallelic 
homozygous deletions or heterozygous mutations, most often associated with LOH. Transcriptome of ZNRF3mutant tumors also showed activation of beta-catenin target genes but to a lesser extent than CTNNB1-mutant tumors, both alterations being mutually exclusive (Assié et al. 2014). Downregulation of ZNRF3 has been described in other types of cancer, including colorectal carcinoma (Bond et al. 2016) and papillary thyroid carcinoma (Qiu et al. 2016).

\section{Insulin-growth-factor II (IGF-II) locus}

Beckwith-Wiedemann syndrome (BWS) is an overgrowth and tumor predisposition syndrome and is clinically heterogeneous. It is characterized by visceromegaly including macroglossia and hemi-hyperplasia, malformations (wall defect, umbilical hernia, ear abnormalities) and predisposition to embryonal malignancies. ACC belongs to BWS tumor spectrum, which also includes Wilms tumor, hepatoblastoma, rhabdomyosarcoma and neuroblastoma with an overall risk for tumor development in children estimated at $7.5 \%$, most of the tumors occurring in the first $8-10$ years of life. Dysregulations at the imprinted 11p15.5 locus, including both genetic and epigenetic alterations, are responsible for the disease. This locus includes 3 main genes: H19, IGF-II and CDKN1C. H19 codes for a long $2.3 \mathrm{~kb}$-noncoding RNA, which has been associated with several cancers and is physiologically only expressed by the maternal allele while IGF-II is only expressed by the paternal allele. Expression of both the genes is regulated by the imprinting center IC1, which is methylated on the paternal allele and unmethylated on the maternal one. CDKN1C, a growth suppression gene, is under the control of another imprinting center IC2. BWS is etiologically heterogeneous arising from dysregulation of one or both imprinting centers and/or imprinted growth regulatory genes on chromosome 11p15.5. Most BWS cases are sporadic and result from loss of maternal methylation at IC2, gain of maternal methylation at IC1 or paternal uniparental disomy; some cases of copy number variations in the $11 \mathrm{p} 15.5$ chromosome region were also described. Hereditary forms of BWS were attributed to mutations in CDKN1C. These different alterations have been described in Libè et al. (2007). Regardless of the causative molecular defect, these alterations all result in IGF-II overexpression (biallelic instead of monoallelic expression) and decrease in $H 19$ expression and/or decrease in CDKN1C expression. Gain of maternal methylation at IC1 or paternal uniparental disomy are associated with a higher risk of tumor development than the other forms suggesting a role of IGF-II overexpression or H19 downregulation in the tumorigenic process (Fig. 4) (Weksberg et al. 2010, Baskin et al. 2014).

At the somatic level, IGF-II overexpression is one of the first molecular abnormalities which has been described in sporadic adult ACC, with a very high prevalence of about 90\%. This increase in expression was associated with DNA demethylation at IGF-II locus, paternal isodisomy in most of cases (Gicquel et al. 1997). Further transcriptome studies confirmed that IGF-II is the most upregulated gene in ACC. IGF-II overexpression is observed in more than $85 \%$ of ACC. Because of such a high prevalence, IGF-II overexpression could not be responsible for the ACC classification derived from transcriptome data by unsupervised clustering, IGF-II-high tumors clustering with IGII-low tumors (De Reyniès et al. 2009). No significant differences in clinical, biological and transcriptomic traits were found between IGF-II-high and IGF-II-low tumors (Guillaud-Bataille et al. 2014). IGF-II was also overexpressed in pediatric adrenocortical tumors, both ACC and adenomas, and the expression of IGF1receptor (IGF1-R), which mediates IGF-II effects in vivo, was more discriminant between malignant (overexpression) and benign tumors in children (Almeida et al. 2008). IGF1-R kinase inhibitor has therefore been developed and were shown to have antitumor effects in both adult and pediatric adrenocortical tumor cell lines (Almeida et al. 2008). However, phase I trials evaluating the feasibility of IGF1-R (Figitumumab and OSI-906) and insulin receptor (OSI-906) inhibition were quite disappointing, only one of 25 patients showing a partial response by RECIST criteria (Haluska et al. 2010, Drelon et al. 2013). This result is concordant with mouse models in which IGF-II overexpression is not sufficient to promote tumorigenesis, even in association with beta-catenin activation (Heaton et al. 2012, Drelon et al. 2013). Overexpression of IGF-II might therefore not be a driver force of adrenal tumorigenesis but maybe simply the reflection of other genetic alterations at the $11 \mathrm{p} 15.5$ locus. Dysregulation of noncoding RNA H19 was described in various types of cancers, including Bcr-Abl-induced leukemia (Guo et al. 2014). H19 promoter was shown to be highly methylated in ACC, leading to a decrease in $H 19$ expression, suggesting a role of H19 in adrenal tumorigenesis (Gao et al. 2002).

\section{Other genetic alterations in ACC}

The MEN1 (multiple endocrine neoplasia) is an autosomal dominant tumor predisposition syndrome, affecting 
At the somatic level, alterations of another pathway

multiple endocrine and non-endocrine tissues. The three main endocrine lesions are primary hyperparathyroidism (95\%), entero-pancreatic neuroendocrine tumors (50\%) and pituitary adenomas (40\%). Tumors are caused by a germline heterozygous mutation ('first hit') of the MEN1 gene, located at the 11q13 locus, followed by a somatic 'secondhit', leading to a complete loss of menin protein function (Agarwal 2013). Adrenal hyperplasia was reported in 20\% of patients with MEN1, among which 10\% had an authentic adrenal tumor. Tumors were associated with hormonal hypersecretion in only 15\% of cases, ACC accounted for $14 \%$ of tumors (Gatta-Cherifi et al. 2012). Somatic mutations of MEN1 in sporadic ACC were recently identified with a prevalence of $7 \%$ in two large cohorts by exome analysis (Assié et al. 2014, Zheng et al. 2016). Menin function is not well characterized, recent studies suggest interaction with transcription regulating factors like JunD or Smad 3.

Lynch syndrome, or hereditary nonpolyposis colorectal cancer (HNPCC) syndrome, is another autosomal dominant tumor predisposition syndrome, secondary to germline heterozygous mutation of DNA-mismatch repair genes (MSH2, MSH6, MLH1 and PMS2). Tumors are usually characterized by the loss of expression of one of these genes, caused by somatic 'second-hit' and microsatellite instability phenotype (Karamurzin et al. 2012). Apart from colorectal cancer, incidence of endometrium, ovaries and urinary tracts cancer is significantly increased in Lynch syndrome. The prevalence of Lynch syndrome in a large cohort of 114 ACC was found to be around 3\% (Raymond et al. 2013), but no somatic mutations of MMR genes have been reported yet, contribution of this molecular alteration to adrenal tumorigenesis remaining unclear.

A very small number of ACC cases were also reported in the context of Carney complex (Anselmo et al. 2012, Morin et al. 2012). The first case was associated with a novel PRKAR1A mutation c.95_96delAA/p.Lys32Argfs*12, subject to nonsense-mediated mRNA decay, and resulting in haploinsufficiency at the protein level. The second case was associated with c.439A>G/p.S147G PRKAR1A mutation, which belongs to the small group of expressed mutant PRKAR1A, not associated with $\mathrm{LOH}$ and thought to exert a negative dominant effect. The very low frequency of malignant adrenal tumors in Carney complex might however suggest the coexistence of additional germline factors predisposing to malignancies (Bertherat 2012). Interestingly, 7 heterozygous inactivating mutations and 3 homozygous deletions of PRKAR1A were identified at the somatic level in a large cohort of sporadic ACC, resulting in increased MEK and BRAF proteins expression (Zheng et al. 2016). of 'DNA preservation', telomere maintenance, were also recently identified. Thus, $73 \%$ of tumors harbored shorter telomeres in comparison to their matched control samples in a large cohort of ACC. (Zheng et al. 2016) TERT (encoding for a telomerase) amplification was reported with a prevalence of about 15\% (Juhlin et al. 2015, Zheng et al. 2016) while mutations in DAXX and $A T R X$, two genes associated with the alternative lengthening of telomeres (ALT) phenotype, were found with a global prevalence of about 10\% (Assié et al. 2014, Zheng et al. 2016).

\section{Genome-wide approaches and identification of prognosis factors}

\section{Transcriptome}

Unsupervised transcriptome-based tumor classification (De Reyniès et al. 2009, Giordano et al. 2009) unraveled two distinct groups of ACC, reflecting tumor proliferation (measured by mitotic counts and cell cycle genes): one group of aggressive proliferating tumors $(\mathrm{C} 1 \mathrm{~A})$, associated with a poor prognosis and one group of less aggressive tumors (C1B), associated with a better outcome. Multivariate analysis including tumor stage and mitotic rate as variables showed that transcriptome data contained independent prognosis information. One of these studies (De Reyniès et al. 2009) also used the transcriptome data to define a two genes predictor of malignancy, using disease-free survival as end point and for malignant tumors, a two genes predictor of survival, using overall survival as end point. The combined expression of $D L G 7$ and PINK1 was the best predictor of disease-free survival, overcoming the uncertainties of intermediary Weiss score, while the combined expression of BUB1B and PINK1 was the best predictor of overall survival in malignant tumors. Unsupervised clustering (Ragazzon et al. 2010) further identified 3 different subgroups in the group of ACC of poor prognosis: one was enriched in TP53 mutations (C1A/p53), the second in beta-catenin cytoplasmic and nuclear accumulation (C1A/beta-catenin) and/or mutations and the third presented neither of these two alterations $(\mathrm{C} 1 \mathrm{~A} / \mathrm{x})$. The delineation of these 3 subgroups relied on different tumorigenesis processes but they were equally associated with a poor prognosis (Fig. 5).

\section{Chromosome alterations}

Chromosome alterations are very frequent in tumor cells, especially in malignancies. In ACC, they were confirmed by different approaches, including conventional CGH 
Transcriptome-based prognosis classification

\begin{tabular}{|c|c|c|c|c|c|}
\hline \multirow[b]{2}{*}{ Atered signaling pathway } & \multicolumn{3}{|c|}{ C1A } & \multicolumn{2}{|c|}{$\mathrm{C} 1 \mathrm{~B}$} \\
\hline & TP53 & 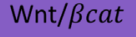 & $\mathrm{x}$ & Wnt $/ \beta c a t$ & $x$ \\
\hline IGF-II expression level & IGFII-low & IGFII-hig & & IGFII-low & IGFII-high \\
\hline Methylation pattern & CIMP-H & CIMP-Low & Non-CIMP & CIMP-LoW & Non-CIMP \\
\hline MiRNA expression & & & Mi 2 & Mi 2 & Mi 1 \\
\hline
\end{tabular}

\section{Figure 5}

Integrated genomic characterization of ACC. According to transcriptome, ACC can be clustered in 2 main groups C1A and C1B, predicting further prognosis of the tumor. In C1A group, associated with poor prognosis, alterations of Wnt/ $/$-catenin and p53 signaling pathway were found, being mostly mutually exclusive; a third subgroup of C1A tumors did not harbor any of these two alterations. In C1B group, associated with a better prognosis, alterations of $\mathrm{Wnt} / \beta$-catenin signaling pathway could be found in a small subgroup of tumors and no $\mathrm{p} 53$ signaling pathway alterations were further identified. No difference of IGF-II expression level was found between C1A and C1B tumors, IGF-II-high tumors accounting for more than $85 \%$ of the tumors in the 2 groups. Interestingly, ACC clustering based on methylation pattern and miRNAs expression seemed to be linked with transcriptomebased clustering. Thus, CIMP-High phenotype was only found in the more aggressive C1A group, CIMP-Low and Non-CIMP phenotype being found in both C1A and C1B tumors but with a large majority of Non-CIMP tumors in C1B group. Concerning miRNAs-based classification, Mi3 tumors were only found in C1A group as well as Mi1 tumors were only found in C1B group; in the contrary, Mi2 tumors could be found in both C1A and C1B groups (Assié et al. 2014, Zheng et al. 2016).

(Kjellman et al. 1996, Zhao et al. 1999), CGH array (Stephan et al. 2008, Szabó et al. 2010, Barreau et al. 2012) and more recently SNP array (Ronchi et al. 2013, Assié et al. 2014). Copy number variations (CNVs) are different and are far more frequent in ACC than in benign adrenal tumors (Kjellman et al. 1996, Zhao et al. 1999, Barreau et al. 2012, Ronchi et al. 2013). The most constant alterations in ACC reported in these different studies include gains in chromosomes 5, 7, 12, 16, 19 and 20 and deletions in chromosome 22. Copy-neutral $\mathrm{LOH}$ was reported with a prevalence of more than $90 \%$ in ACC (Ronchi et al. 2013). SNP array analysis in a large European cohort (ENSAT: European network for the Study of Adrenal Tumors) (Assié et al. 2014) unraveled several recurrent gene amplifications or deletions in ACC, including high-level amplifications of TERT and CDK 4 and homozygous deletions of CDKN2A, RB1, ZNRF3, 3q13.1 and 4q34.3 loci. Both loci include a long noncoding RNA, respectively, LOC285194 and LINC00290, whose implication in cancer is increasingly being appreciated. Concerning prognosis marker identification, a precise genetic pattern (i.e. large gains at chr 5, 7, 12 and 19 and losses at chr 1, 2, 13, 17, and 22) was associated with a better prognosis (Ronchi et al. 2013). An international large cohort of ACC, investigated by the TCGA program, further analyzed chromosomal alterations in ACC. By a detailed bioinformatics analysis, the TCGA study revealed a subgroup of ACC with numerous chromosomal alterations (the 'noisy' phenotype) and presenting a poor prognosis. This analysis also revealed a quite unique feature of ACC by comparison with other solid cancers investigated by the same program with a sequential development going from hypodiploidy to polyploidy via whole genome doubling in a subset of ACC (Zheng et al. 2016).

\section{Methylome}

DNA methylation is the most investigated epigenetic modification, regulating gene expression and stable gene silencing. DNA methyltransferases allow covalent addition of a methyl group on cytosine within CpG dinucleotides, which are clustered in specific promoter regions, called 'CpG islands'. Alterations in methylation pattern have been associated with cancer development. Inactivation of certain tumor suppressor genes was reported to occur as a consequence of promoter hypermethylation and genomic instability as a consequence of global hypomethylation, both being responsible for cell transformation (Kulis \& Esteller 2010). The first genome-wide study of adrenal tumor DNA methylation compared methylation levels of 27,578 CpG sites in adrenocortical normal tissue samples, adenomas and carcinomas and identified a total of 212 CpG islands significantly hypermethylated in ACC, responsible for a decrease in expression of genes involved in cell cycle and apoptosis regulation (CDKN2A, GATA4, DLEC1, HDAC10, PYCARD, SCGB3A1/HIN1) (Fonseca et al. 2012). Another study reported a global hypomethylation pattern in ACC associated with hypermethylation of specific promoter regions responsible for downregulation 
of the expression of a certain number of genes (Rechache et al. 2012). A third study reported a negative correlation between methylation and expression for a total of 1741 genes of 12,250 studied, among the top genes were found H19 and other tumor suppressor genes. This last study further used unsupervised clustering of DNA methylation profiles, unraveling two groups of carcinomas, one with an elevated methylation level, in favor of a CpG island methylator phenotype (CIMP) and the other with a methylation level only slightly increased in comparison to adenomas (non-CIMP). CIMP group could be further divided into 2 subgroups with two different methylation levels (CIMP high and CIMP low). Hypermethylation was associated with a poor survival (Barreau et al. 2013). This was further confirmed in a recent study, which showed that tumor methylation status was a significant prognostic factor of disease-free survival (DFS) and overall survival (OS) (Jouinot et al. 2016). Jouinot and coworkers identified a strong methylation marker, taking into account mean methylation of 4 genes (PAX5, GSTP1, PYCARD and PAX6). More interestingly, they showed that this biomarker remained a significant prognostic factor for DFS and OS in multivariate analysis including ENSAT stage and Ki67. This biomarker seems particularly attractive, most of the previous reported molecular markers being only investigated in univariate analysis of survival (Jouinot et al. 2016). Integrative approaches confronting transcriptome and methylome data found that CIMP-high phenotype was only found in $\mathrm{C} 1 \mathrm{~A} / \mathrm{x}$ and $\mathrm{C} 1 \mathrm{~A} / \mathrm{p} 53$ tumors while non-CIMP phenotype was observed in C1A/beta-catenin and C1B tumors (Barreau et al. 2013, Assié et al. 2014). For a review of methylation dysregulation in ACC, see Jonker et al. (2017).

\section{miRome}

MicroRNAs (miRNAs) are small noncoding RNAs of approximately 22 nucleotides, regulating gene expression at the posttranscriptional level by targeting mRNAs for cleavage or translation repression. They are involved in the pathogenesis of several neoplasms, their deregulation being responsible for both oncogene activation and tumor suppressor genes silencing. Their profile of expression can serve as diagnostic and/or prognosis markers, their possible detection in blood samples making them easily accessible. They also open the way for new therapeutic perspectives (Lujambio \& Lowe 2012). Deregulation of several miRNAs were described in ACC, the most frequently reported being downregulation of miR-335 and miR-195 and upregulation of miR-483-5p (Soon et al. 2009, Özata et al. 2011, Patterson et al. 2011, Schmitz et al.
2011, Chabre et al. 2013, Patel et al. 2013). Some of these alterations, including downregulation of miR-195 and upregulation of miR-483-5p and also of miR-503, miR-1202 and miR-1275 were associated with a poor DFS (Soon et al. 2009, Özata et al. 2011). Upregulation of miR-483-3p was also reported in ACC leading to a decrease in protein expression of PUMA (p53-upregulated modulator of apoptosis), a proapoptotic factor (Özata et al. 2011). Other miRNAs were reported to be deregulated in childhood ACC, including miR-99a and miR-100. Functional analysis in ACT cell lines showed that they coordinately regulate the expression of insulin-like growth factormTOR-raptor signaling pathway through binding in their 3'-UTR. Everolimus, a pharmacological agent inhibiting mTOR pathway, was reported to reduce cell growth in vitro and in vivo (Doghman et al. 2010). Interestingly, some circulating serum miRNAs are detectable and can be used as diagnosis or prognosis biomarkers. Thus, detectable miR-483-5p in serum was specific of ACC and high levels of circulating miR-483-5-p associated with low levels of circulating miR-195 were associated with poor prognosis (Chabre et al. 2013). Hierarchical clustering analysis of miRNAs expression profile identified 3 stable tumor clusters associated with different prognosis (Özata et al. 2011, Assié et al. 2014). Cluster Mi1 tumors showed the largest differences of miR expression with normal adrenal tissue. Cluster Mi3 tumors were associated with a worse prognosis. In an integrative point of view, C1A tumors included almost all Mi3 tumors, whereas C1B tumors belonged to Mi1 or Mi2 clusters (Assié et al. 2014).

\section{Conclusion}

Development of genome-wide approaches allowed considerable progress in adrenocortical tumorigenesis understanding, identifying alterations in different signaling pathways. This opens several perspectives including the development of diagnosis and prognosis biomarkers and the identification of new therapeutic targets. These advances are particularly important in the context of ACC whose prognosis remained very poor.

\section{Declaration of interest}

The authors declare that there is no conflict of interest that could be perceived as prejudicing the impartiality of this review.

\section{Funding}

Our studies are supported by the Programme Hospitalier de Recherche Clinique to the COMETE network (COMETE-TACTIC) and the Cony-Maeva and Promex Foundations (to J. Bertherat's Laboratory). 


\section{Acknowledgments}

The authors wish to thank the members of our laboratories and the COMETE and ENSAT networks for support and discussions.

\section{References}

Agarwal SK 2013 Multiple endocrine neoplasia type 1. Frontiers of Hormone Research 41 1-15. (https://doi.org/10.1159/000345666)

Åkerström T, Carling T, Beuschlein F \& Hellman P 2016 Genetics of adrenocortical tumours. Journal of Internal Medicine 280 540-550. (https://doi.org/10.1111/joim.12452)

Albiger NM, Regazzo D, Rubin B, Ferrara AM, Rizzati S, Taschin E, Ceccato F, Arnaldi G, Pecori Giraldi F, Stigliano A, et al. 2017 A multicenter experience on the prevalence of ARMC5 mutations in patients with primary bilateral macronodular adrenal hyperplasia: from genetic characterization to clinical phenotype. Endocrine $\mathbf{5 5}$ 959-968. (https://doi.org/10.1007/s12020-016-0956-z)

Almeida MQ, Fragoso MCBV, Lotfi CFP, Santos MG, Nishi MY, Costa MHS, Lerario AM, Maciel CC, Mattos GE, Jorge AAL, et al. 2008 Expression of insulin-like growth factor-II and its receptor in pediatric and adult adrenocortical tumors. Journal of Clinical Endocrinology and Metabolism 93 3524-3531. (https://doi. org/10.1210/jc.2008-0065)

Almeida MQ, Azevedo MF, Xekouki P, Bimpaki EI, Horvath A, Collins MT, Karaviti LP, Jeha GS, Bhattacharyya N, Cheadle C, et al. 2012 Activation of cyclic AMP signaling leads to different pathway alterations in lesions of the adrenal cortex caused by germline PRKAR1A defects versus those due to somatic GNAS mutations. Journal of Clinical Endocrinology and Metabolism 97 E687-E693. (https://doi.org/10.1210/jc.2011-3000)

Anselmo J, Medeiros S, Carneiro V, Greene E, Levy I, Nesterova M, Lyssikatos C, Horvath A, Carney JA \& Stratakis CA 2012 A large family with carney complex caused by the S147G PRKAR1A mutation shows a unique spectrum of disease including adrenocortical cancer. Journal of Clinical Endocrinology and Metabolism 97 351-359. (https://doi.org/10.1210/jc.2011-2244)

Arlt W, Biehl M, Taylor AE, Hahner S, Libé R, Hughes BA, Schneider P, Smith DJ, Stiekema H, Krone N, et al. 2011 Urine steroid metabolomics as a biomarker tool for detecting malignancy in adrenal tumors. Journal of Clinical Endocrinology and Metabolism 96 3775-3784. (https://doi.org/10.1210/jc.2011-1565)

Assie G, Giordano TJ \& Bertherat J 2012 Gene expression profiling in adrenocortical neoplasia. Molecular and Cellular Endocrinology 351 111-117. (https://doi.org/10.1016/j.mce.2011.09.044)

Assié G, Libé R, Espiard S, Rizk-Rabin M, Guimier A, Luscap W, Barreau O, Lefèvre L, Sibony M, Guignat L, et al. 2013 ARMC5 mutations in macronodular adrenal hyperplasia with Cushing's syndrome. New England Journal of Medicine 369 2105-2114. (https:// doi.org/10.1056/NEJMoa1304603)

Assié G, Letouzé E, Fassnacht M, Jouinot A, Luscap W, Barreau O, Omeiri H, Rodriguez S, Perlemoine K, René-Corail F, et al. 2014 Integrated genomic characterization of adrenocortical carcinoma. Nature Genetics 46 607-612. (https://doi.org/10.1038/ng.2953)

Barreau O, De Reynies A, Wilmot-Roussel H, Guillaud-Bataille M, Auzan C, René-Corail F, Tissier F, Dousset B, Bertagna X, Bertherat J, et al. 2012 Clinical and pathophysiological implications of chromosomal alterations in adrenocortical tumors: an integrated genomic approach. Journal of Clinical Endocrinology and Metabolism 97 301-311. (https://doi.org/10.1210/jc.2011-1588)

Barreau O, Assié G, Wilmot-Roussel H, Ragazzon B, Baudry C, Perlemoine K, René-Corail F, Bertagna X, Dousset B, Hamzaoui N, et al. 2013 Identification of a CpG island methylator phenotype in adrenocortical carcinomas. Journal of Clinical Endocrinology and Metabolism 98 174-184. (https://doi.org/10.1210/jc.2012-2993)
Baskin B, Choufani S, Chen YA, Shuman C, Parkinson N, Lemyre E, Micheil Innes A, Stavropoulos DJ, Ray PN \& Weksberg R 2014 High frequency of copy number variations (CNVs) in the chromosome $11 \mathrm{p} 15$ region in patients with Beckwith-Wiedemann syndrome. Human Genetics 133 321-330. (https://doi.org/10.1007/s00439-0131379-z)

Bertherat J 2012 Adrenocortical cancer in carney complex: a paradigm of endocrine tumor progression or an association of genetic predisposing factors? Journal of Clinical Endocrinology and Metabolism 97 387-390. (https://doi.org/10.1210/jc.2011-3327)

Bertherat J, Mosnier-Pudar H \& Bertagna X 2002 Adrenal incidentalomas. Current Opinion in Oncology 14 58-63. (https://doi. org/10.1097/00001622-200201000-00011)

Bertherat J, Groussin L, Sandrini F, Matyakhina L, Bei T, Stergiopoulos S, Papageorgiou T, Bourdeau I, Kirschner LS, Vincent-Dejean C, et al. 2003 Molecular and functional analysis of PRKAR1A and its locus (17q22-24) in sporadic adrenocortical tumors: $17 \mathrm{q}$ losses, somatic mutations, and protein kinase A expression and activity. Cancer Research 63 5308-5319. (https://doi.org/10.1210/jc.2008-2333)

Bertherat J, Horvath A, Groussin L, Grabar S, Boikos S, Cazabat L, Libe R, René-Corail F, Stergiopoulos S, Bourdeau I, et al. 2009 Mutations in regulatory subunit type $1 \mathrm{~A}$ of cyclic adenosine 5 '-monophosphate-dependent protein kinase (PRKAR1A): phenotype analysis in 353 patients and 80 different genotypes. Journal of Clinical Endocrinology and Metabolism 94 2085-2091. (https://doi. org/10.1210/jc.2008-2333)

Berthon A, Sahut-Barnola I, Lambert-Langlais S, de Joussineau C, Damon-Soubeyrand C, Louiset E, Taketo MM, Tissier F, Bertherat J, Lefrançois-Martinez A-M, et al. 2010 Constitutive beta-catenin activation induces adrenal hyperplasia and promotes adrenal cancer development. Human Molecular Genetics 19 1561-1576. (https://doi. org/10.1093/hmg/ddq029)

Berthon A, Martinez A, Bertherat J \& Val P 2012 Wnt/B-catenin signalling in adrenal physiology and tumour development. Molecular and Cellular Endocrinology 351 87-95. (https://doi.org/10.1016/j. mce.2011.09.009)

Berthon A, Faucz F, Bertherat J \& Stratakis CA 2017a Analysis of ARMC5 expression in human tissues. Molecular and Cellular Endocrinology 441 140-145. (https://doi.org/10.1016/j.mce.2016.08.018)

Berthon A, Faucz FR, Espiard S, Drougat L, Bertherat J \& Stratakis CA 2017b Age-dependent effects of Armc5 haploinsufficiency on adrenocortical function. Human Molecular Genetics 26 3495-3507. (https://doi.org/10.1093/hmg/ddx235)

Beuschlein F, Reincke M, Königer M, D'Orazio D, Dobbie Z \& Rump LC 2000 Cortisol producing adrenal adenoma - a new manifestation of Gardner's syndrome. Endocrine Research 26 783-790. (https://doi. org/10.3109/07435800009048600)

Beuschlein F, Fassnacht M, Assié G, Calebiro D, Stratakis CA, Osswald A, Ronchi CL, Wieland T, Sbiera S, Faucz FR, et al. 2014 Constitutive activation of PKA catalytic subunit in adrenal Cushing's syndrome. New England Journal of Medicine 370 1019-1028. (https://doi. org/10.1056/NEJMoa1310359)

Bond CE, McKeone DM, Kalimutho M, Bettington ML, Pearson S-A, Dumenil TD, Wockner LF, Burge M, Leggett BA \& Whitehall VLJ 2016 RNF43 and ZNRF3 are commonly altered in serrated pathway colorectal tumorigenesis. Oncotarget 7 70589-70600. (https://doi. org/10.18632/oncotarget.12130)

Bonnet S, Gaujoux S, Launay P, Baudry C, Chokri I, Ragazzon B, Libé R, René-Corail F, Audebourg A, Vacher-Lavenu MC, et al. 2011 Wnt/קcatenin pathway activation in adrenocortical adenomas is frequently due to somatic CTNNB1-activating mutations, which are associated with larger and nonsecreting tumors: a study in cortisol-secreting and -nonsecreting tumors. Journal of Clinical Endocrinology and Metabolism 96 419-426. (https://doi.org/10.1210/jc.2010-1885)

Bougeard G, Sesboüé R, Baert-Desurmont S, Vasseur S, Martin C, Tinat J, Brugières L, Chompret A, de Paillerets BB, Stoppa-Lyonnet D, et al. (c) 2018 Society for Endocrinology Published by Bioscientifica Ltd. Printed in Great Britain 
2008 Molecular basis of the Li-Fraumeni syndrome: an update from the French LFS families. Journal of Medical Genetics 45 535-538. (https://doi.org/10.1136/jmg.2008.057570)

Bourdeau I, Oble S, Magne F, Lévesque I, Cáceres-Gorriti KY, Nolet S, Awadalla P, Tremblay J, Hamet P, Fragoso MCBV, et al. 2016 ARMC5 mutations in a large French-Canadian family with cortisol-secreting $\beta$-adrenergic/vasopressin responsive bilateral macronodular adrenal hyperplasia. European Journal of Endocrinology 174 85-96. (https://doi. org/10.1530/EJE-15-0642)

Calebiro D, Hannawacker A, Lyga S, Bathon K, Zabel U, Ronchi C, Beuschlein F, Reincke M, Lorenz K, Allolio B, et al. 2014 PKA catalytic subunit mutations in adrenocortical Cushing's adenoma impair association with the regulatory subunit. Nature Communications 5 5680. (https://doi.org/10.1038/ncomms6680)

Cao Y, He M, Gao Z, Peng Y, Li Y, Li L, Zhou W, Li X, Zhong X, Lei Y, et al. 2014 Activating hotspot L205R mutation in PRKACA and adrenal Cushing's syndrome. Science 344 913-917. (https://doi. org/10.1126/science.1249480)

Casey M, Mah C, Merliss AD, Kirschner LS, Taymans SE, Denio AE, Korf B, Irvine AD, Hughes A, Carney JA, et al. 1998 Identification of a novel genetic locus for familial cardiac myxomas and Carney complex. Circulation 98 2560-2566. (https://doi.org/10.1161/01. CIR.98.23.2560)

Chabre O, Libé R, Assie G, Barreau O, Bertherat J, Bertagna X, Feige JJ \& Cherradi N 2013 Serum miR-483-5p and miR-195 are predictive of recurrence risk in adrenocortical cancer patients. Endocrine-Related Cancer 20 579-594. (https://doi.org/10.1530/ERC-13-0051)

Chapman A, Durand J, Ouadi L \& Bourdeau I 2011 Identification of genetic alterations of AXIN2 gene in adrenocortical tumors. Journal of Clinical Endocrinology and Metabolism 96 E1477-E1481. (https:// doi.org/10.1210/jc.2010-2987)

Correa R, Zilbermint M, Berthon A, Espiard S, Batsis M, Papadakis GZ, Xekouki P, Lodish MB, Bertherat J, Faucz FR, et al. 2015 The ARMC5 gene shows extensive genetic variance in primary macronodular adrenocortical hyperplasia. European Journal of Endocrinology $\mathbf{1 7 3}$ 435-440. (https://doi.org/10.1530/EJE-15-0205)

Custódio G, Parise GA, Kiesel Filho N, Komechen H, Sabbaga CC, Rosati R, Grisa L, Parise IZS, Pianovski MAD, Fiori CMCM, et al. 2013 Impact of neonatal screening and surveillance for the TP53 R337H mutation on early detection of childhood adrenocortical tumors. Journal of Clinical Oncology 31 2619-2626. (https://doi.org/10.1200/ JCO.2012.46.3711)

Di Dalmazi G, Kisker C, Calebiro D, Mannelli M, Canu L, Arnaldi G, Quinkler M, Rayes N, Tabarin A, Laure Jullié M, et al. 2014 Novel somatic mutations in the catalytic subunit of the protein kinase A as a cause of adrenal Cushing's syndrome: a European Multicentric Study. Journal of Clinical Endocrinology and Metabolism 99 E2093-E2100. (https://doi.org/10.1210/jc.2014-2152)

Demeure MJ, Coan KE, Grant CS, Komorowski RA, Stephan E, Sinari S, Mount D \& Bussey KJ 2013 PTTG1 overexpression in adrenocortical cancer is associated with poor survival and represents a potential therapeutic target. Surgery 154 1405-1416. (https://doi.org/10.1016/j. surg.2013.06.058)

Doghman M, El Wakil A, Cardinaud B, Thomas E, Wang J, Zhao W, Peralta-Del Valle MHC, Figueiredo BC, Zambetti GP \& Lalli E 2010 Regulation of insulin-like growth factor-mammalian target of rapamycin signaling by microRNA in childhood adrenocortical tumors. Cancer Research 70 4666-4675. (https://doi. org/10.1158/0008-5472.CAN-09-3970)

Drelon C, Berthon A \& Val P 2013 Adrenocortical cancer and IGF2: is the game over or our experimental models limited? Journal of Clinical Endocrinology and Metabolism 98 505-507. (https://doi org/10.1210/jc.2012-3310)

Elbelt U, Trovato A, Kloth M, Gentz E, Finke R, Spranger J, Galas D, Weber S, Wolf C, König K, et al. 2015 Molecular and clinical evidence for an ARMC5 tumor syndrome: concurrent inactivating germline and somatic mutations are associated with both primary macronodular adrenal hyperplasia and meningioma. Journal of Clinical Endocrinology and Metabolism 100 E119-E128. (https://doi. org/10.1210/jc.2014-2648)

Espiard S \& Bertherat J 2015 The genetics of adrenocortical tumors. Endocrinology and Metabolism Clinics of North America 44 311-334. (https://doi.org/10.1016/j.ecl.2015.02.004)

Espiard S, Drougat L, Libé R, Assié G, Perlemoine K, Guignat L, Barrande G, Brucker-Davis F, Doullay F, Lopez S, et al. 2015 ARMC5 mutations in a large cohort of primary macronodular adrenal hyperplasia: clinical and functional consequences. Journal of Clinical Endocrinology and Metabolism 100 E926-E935. (https://doi. org/10.1210/jc.2014-4204)

Faria AM \& Almeida MQ 2012 Differences in the molecular mechanisms of adrenocortical tumorigenesis between children and adults. Molecular and Cellular Endocrinology 351 52-57. (https://doi. org/10.1016/j.mce.2011.09.040)

Fassnacht M, Johanssen S, Quinkler M, Bucsky P, Willenberg HS, Beuschlein F, Terzolo M, Mueller HH, Hahner S \& Allolio B 2009 Limited prognostic value of the 2004 international union against cancer staging classification for adrenocortical carcinoma. Cancer 115 243-250. (https://doi.org/10.1002/cncr.24030)

Fassnacht M, Arlt W, Bancos I, Dralle H, Newell-Price J, Sahdev A, Tabarin A, Terzolo M, Tsagarakis S \& Dekkers OM 2016 Management of adrenal incidentalomas: European Society of Endocrinology Clinical Practice Guideline in collaboration with the European Network for the Study of adrenal tumors. European Journal of Endocrinology 175 G1-G34. (https://doi.org/10.1530/EJE-16-0467)

Faucz FR, Zilbermint M, Lodish MB, Szarek E, Trivellin G, Sinaii N, Berthon A, Libé R, Assié G, Espiard S, et al. 2014 Macronodular adrenal hyperplasia due to mutations in an armadillo repeat containing 5 (ARMC5) gene: a clinical and genetic investigation. Journal of Clinical Endocrinology and Metabolism 99 E1113-E1119. (https://doi.org/10.1210/jc.2013-4280)

Fonseca AL, Kugelberg J, Starker LF, Scholl U, Choi M, Hellman P, Åkerström G, Westin G, Lifton RP, Björklund P, et al. 2012 Comprehensive DNA methylation analysis of benign and malignant adrenocortical tumors. Genes, Chromosomes and Cancer 51 949-960. (https://doi.org/10.1002/gcc.21978)

Forlino A, Vetro A, Garavelli L, Ciccone R, London E, Stratakis CA \& Zuffardi O 2014 PRKACB and Carney complex. New England Journal of Medicine 370 1065-1067. (https://doi.org/10.1056/NEJMc1309730)

Fragoso MCBV, Domenice S, Latronico AC, Martin RM, Pereira MAA, Zerbini MCN, Lucon AM \& Mendonca BB 2003 Cushing's syndrome secondary to adrenocorticotropin-independent macronodular adrenocortical hyperplasia due to activating mutations of GNAS1 gene. Journal of Clinical Endocrinology and Metabolism 88 2147-2151. (https://doi.org/10.1210/jc.2002-021362)

Gagliardi L, Hotu C, Casey G, Braund WJ, Ling K-H, Dodd T, Manavis J, Devitt PG, Cutfield R, Rudzki Z, et al. 2009 Familial vasopressinsensitive ACTH-independent macronodular adrenal hyperplasia (VPsAIMAH): clinical studies of three kindreds. Clinical Endocrinology 70 883-891. (https://doi.org/10.1111/j.1365-2265.2008.03471.x)

Gao ZH, Suppola S, Liu J, Heikkilä P, Jänne J \& Voutilainen R 2002 Association of H19 promoter methylation with the expression of H19 and IGF-II genes in adrenocortical tumors. Journal of Clinical Endocrinology and Metabolism 87 1170-1176. (https://doi. org/10.1210/jc.87.3.1170)

Gatta-Cherifi B, Chabre O, Murat A, Niccoli P, Cardot-Bauters C, Rohmer V, Young J, Delemer B, Du Boullay H, Verger MF, et al. 2012 Adrenal involvement in MEN1. Analysis of 715 cases from the Groupe d'étude des Tumeurs Endocrines database. European Journal of Endocrinology 166 269-279. (https://doi.org/10.1530/EJE-11-0679)

Gaujoux S, Tissier F, Groussin L, Libé R, Ragazzon B, Launay P, Audebourg A, Dousset B, Bertagna X \& Bertherat J $2008 \mathrm{Wnt} / \beta$ catenin and $3^{\prime}, 5^{\prime}$-cyclic adenosine $5^{\prime}$-monophosphate/protein kinase
2018 Society for Endocrinology Published by Bioscientifica Ltd. Printed in Great Britain 
a signaling pathways alterations and somatic $\beta$-catenin gene mutations in the progression of adrenocortical tumors. Journal of Clinical Endocrinology and Metabolism 93 4135-4140. (https://doi. org/10.1210/jc.2008-0631)

Gaujoux S, Pinson S, Gimenez-Roqueplo A-P, Amar L, Ragazzon B, Launay P, Meatchi T, Libé R, Bertagna X, Audebourg A, et al. 2010 Inactivation of the APC gene is constant in adrenocortical tumors from patients with familial adenomatous polyposis but not frequent in sporadic adrenocortical cancers. Clinical Cancer Research $\mathbf{1 6}$ 5133-5141. (https://doi.org/10.1158/1078-0432.CCR-10-1497)

Gaujoux S, Grabar S, Fassnacht M, Ragazzon B, Launay P, Libé R, Chokri I, Audebourg A, Royer B, Sbiera S, et al. $2011 \beta$-catenin activation is associated with specific clinical and pathologic characteristics and a poor outcome in adrenocortical carcinoma. Clinical Cancer Research 17 328-336. (https://doi.org/10.1158/1078-0432.CCR-10-2006)

Gicquel C, Raffin-Sanson ML, Gaston V, Bertagna X, Plouin PF, Schlumberger M, Louvel A, Luton JP \& Le Bouc Y 1997 Structural and functional abnormalities at $11 \mathrm{p} 15$ are associated with the malignant phenotype in sporadic adrenocortical tumors: study on a series of 82 tumors. Journal of Clinical Endocrinology and Metabolism 82 2559-2565. (https://doi.org/10.1210/jcem.82.8.4170)

Gicquel C, Bertagna X, Gaston V, Coste J, Louvel A, Baudin E, Bertherat J, Chapuis Y, Duclos JM, Schlumberger M, et al. 2001 Molecular markers and long-term recurrences in a large cohort of patients with sporadic adrenocortical tumors. Cancer Research $\mathbf{6 1}$ 6762-6767.

Giordano TJ, Kuick R, Else T, Gauger PG, Vinco M, Bauersfeld J, Sanders D, Thomas DG, Doherty G \& Hammer G 2009 Molecular classification and prognostication of adrenocortical tumors by transcriptome profiling. Clinical Cancer Research 15 668-676. (https:// doi.org/10.1158/1078-0432.CCR-08-1067)

Goh G, Scholl UI, Healy JM, Choi M, Prasad ML, Nelson-Williams C, Kuntsman JW, Korah R, Suttorp A-C, Dietrich D, et al. 2014 Recurrent activating mutation in PRKACA in cortisol-producing adrenal tumors. Nature Genetics 46 613-617. (https://doi. org/10.1038/ng.2956)

Groussin L, Kirschner LS, Vincent-dejean C, Perlemoine K, Jullian E, Delemer B, Zacharieva S, Pignatelli D, Carney JA, Luton JP, et al. 2002 Molecular analysis of the cyclic AMP-dependent protein kinase A (PKA) regulatory subunit $1 \mathrm{~A}$ (PRKAR1A) gene in patients with Carney Complex and primary pigmented nodular adrenocortical disease (PPNAD) reveals novel mutations and clues for pathophysiology. American Journal of Human Genetics 71 1433-1442. (https://doi.org/10.1086/344579)

Grumbach MM, Biller BMK, Braunstein GD, Campbell KK, Carney JA, Godley PA, Harris EL, Lee JKT, Oertel YC, Posner MC, et al. 2003 Management of the clinically inapparent adrenal mass ('incidentaloma'). Annals of Internal Medicine 138 424-429. (https:// doi.org/10.7326/0003-4819-138-5-200303040-00013)

Guillaud-Bataille M, Ragazzon B, de Reyniès A, Chevalier C, Francillard I, Barreau O, Steunou V, Guillemot J, Tissier F, RizkRabin M, et al. 2014 IGF2 promotes growth of adrenocortical carcinoma cells, but its overexpression does not modify phenotypic and molecular features of adrenocortical carcinoma. PLOS ONE 9 e103744. (https://doi.org/10.1371/journal.pone.0103744)

Guimier A, Ragazzon B, Assié G, Tissier F, Dousset B, Bertherat J \& Gaujoux S 2013 AXIN genetic analysis in adrenocortical carcinomas updated. Journal of Endocrinological Investigation 36 1000-1003. (https://doi.org/10.3275/9022)

Guo G, Kang Q, Chen Q, Chen Z, Wang J, Tan L \& Chen JL 2014 High expression of long non-coding RNA H19 is required for efficient tumorigenesis induced by Bcr-Abl oncogene. FEBS Letters $\mathbf{5 8 8}$ 1780-1786. (https://doi.org/10.1016/j.febslet.2014.03.038)

Half E, Bercovich D \& Rozen P 2009 Familial adenomatous polyposis. Orphanet Journal of Rare Diseases 4 22. (https://doi.org/10.1186/17501172-4-22)
Haluska P, Worden F, Olmos D, Yin D, Schteingart D, Batzel GN, Paccagnella ML, De Bono JS, Gualberto A \& Hammer GD 2010 Safety, tolerability, and pharmacokinetics of the anti-IGF-1R monoclonal antibody figitumumab in patients with refractory adrenocortical carcinoma. Cancer Chemotherapy and Pharmacology 65 765-773. (https://doi.org/10.1007/s00280-009-1083-9)

Heaton JH, Wood MA, Kim AC, Lima LO, Barlaskar FM, Almeida MQ, Fragoso MCBV, Kuick R, Lerario AM, Simon DP, et al. 2012 Progression to adrenocortical tumorigenesis in mice and humans through insulin-like growth factor 2 and $\beta$-catenin. American Journal of Pathology 181 1017-1033. (https://doi.org/10.1016/j. ajpath.2012.05.026)

Heinze B, Herrmann LJM, Fassnacht M, Ronchi CL, Willenberg HS, Quinkler M, Reisch N, Zink M, Allolio B \& Hahner S 2014 Less common genotype variants of TP53 polymorphisms are associated with poor outcome in adult patients with adrenocortical carcinoma. European Journal of Endocrinology 170 707-717. (https://doi. org/10.1530/EJE-13-0788)

Hofland J, Hofland LJ, van Koetsveld PM, Steenbergen J, de Herder WW, van Eijck $\mathrm{CH}$, de Krijger RR, van Nederveen FH, van Aken MO, de Groot JW, et al. 2013 ACTH-independent macronodular adrenocortical hyperplasia reveals prevalent aberrant in vivo and in vitro responses to hormonal stimuli and coupling of argininevasopressin type 1a receptor to $11 \beta$-hydroxylase. Orphanet Journal of Rare Diseases 8 142. (https://doi.org/10.1186/1750-1172-8-142)

Horvath A, Boikos S, Giatzakis C, Robinson-White A, Groussin L, Griffin KJ, Stein E, Levine E, Delimpasi G, Hsiao HP, et al. 2006 A genome-wide scan identifies mutations in the gene encoding phosphodiesterase 11A4 (PDE11A) in individuals with adrenocortical hyperplasia. Nature Genetics 38 794-800. (https://doi.org/10.1038/ ng1809)

Horvath A, Mericq V \& Stratakis CA 2008 Mutation in PDE8B, a cyclic AMP-specific phosphodiesterase in adrenal hyperplasia. New England Journal of Medicine 358 750-752. (https://doi.org/10.1056/ NEJMc0706182)

Hsiao H-P, Kirschner LS, Bourdeau I, Keil MF, Boikos SA, Verma S, Robinson-White AJ, Nesterova M, Lacroix A \& Stratakis CA 2009 Clinical and genetic heterogeneity, overlap with other tumor syndromes, and atypical glucocorticoid hormone secretion in adrenocorticotropin-independent macronodular adrenal hyperplasia compared with other adrenocortical tumors. Journal of Clinical Endocrinology and Metabolism 94 2930-2937. (https://doi. org/10.1210/jc.2009-0516)

Hu Y, Lao L, Mao J, Jin W, Luo H, Charpentier T, Qi S, Peng J, Hu B, Marcinkiewicz MM, et al. 2017 Armc5 deletion causes developmental defects and compromises T-cell immune responses. Nature Communications 8 13834. (https://doi.org/10.1038/ncomms13834)

Imöhl M, Köditz R, Stachon A, Müller K-M, Nicolas V, Pfeilschifter J \& Krieg M 2002 Catecholamine-dependent hereditary Cushing's syndrome - follow-up after unilateral adrenalectomy. Medizinische Klinik 97 747-753. (https://doi.org/10.1007/s00063-002-1220-2)

Jonker PKC, Meyer VM \& Kruijff S 2017 Molecular and cellular endocrinology epigenetic dysregulation in adrenocortical carcinoma, a systematic review of the literature. Molecular and Cellular Endocrinology [epub]. (https://doi.org/10.1016/j.mce.2017.08.009)

Jouinot A, Assié G, Libe R, Fassnacht M, Papathomas T, Barreau O, De la Villeon B, Faillot S, Hamzaoui N, Neou M, et al. 2016 DNA methylation is an independent prognostic marker of survival in adrenocortical cancer. Journal of Clinical Endocrinology and Metabolism 102 923-932. (https://doi.org/10.1210/jc.2016-3205)

Juhlin CC, Goh G, Healy JM, Fonseca AL, Scholl UI, Stenman A, Kunstman JW, Brown TC, Overton JD, Mane SM, et al. 2015 Wholeexome sequencing characterizes the landscape of somatic mutations and copy number alterations in adrenocortical carcinoma. Journal of Clinical Endocrinology and Metabolism 100 E493-E502. (https://doi. org/10.1210/jc.2014-3282) 
Karamurzin Y, Zeng Z, Stadler ZK, Zhang L, Ouansafi I, Al-Ahmadie HA, Sempoux C, Saltz LB, Soslow RA, O'Reilly EM, et al. 2012 Unusual DNA mismatch repair-deficient tumors in Lynch syndrome: a report of new cases and review of the literature. Human Pathology $\mathbf{4 3}$ 1677-1687. (https://doi.org/10.1016/j.humpath.2011.12.012)

Kebebew E, Reiff E, Duh Q, Clark OH \& McMillan A 2006 Extent of disease at presentation and outcome for adrenocortical carcinoma: have we made progress? World Journal of Surgery 30 872-878. (https://doi.org/10.1007/s00268-005-0329-x)

Kerkhofs TMA, Verhoeven RHA, Maarten J, Der Zwan V, Dieleman J, Kerstens MN, Links TP, Van de Poll-franse LV \& Haak HR 2013 Adrenocortical carcinoma : a population-based study on incidence and survival in the Netherlands since 1993. European Journal of Cancer 49 2579-2586. (https://doi.org/10.1016/j.ejca.2013.02.034)

Kirschner LS, Carney JA, Pack SD, Taymans SE, Giatzakis C, Cho YS, Cho-Chung YS \& Stratakis CA 2000 Mutations of the gene encoding the protein kinase A type I-alpha regulatory subunit in patients with the Carney complex. Nature Genetics 26 89-92. (https://doi. org/10.1038/79238)

Kjellman M, Kallioniemi OP, Karhu R, Höög A, Farnebo LO, Auer G, Larsson C \& Bäckdahl M 1996 Genetic aberrations in adrenocortical tumors detected using comparative genomic hybridization correlate with tumor size and malignancy. Cancer Research 56 4219-4223.

Kobayashi H, Usui T, Fukata J, Yoshimasa T, Oki Y \& Nakao K 2000 Mutation analysis of Gsalpha, adrenocorticotropin receptor and p53 genes in Japanese patients with adrenocortical neoplasms: including a case of Gsalpha mutation. Endocrine Journal 47 461-466. (https:// doi.org/10.1507/endocrj.47.461)

Kulis M \& Esteller M 2010 DNA methylation and cancer. Advances in Genetics 70 27-56. (https://doi.org/10.1016/B978-0-12-380866$0.60002-2)$

Lacroix A, Hamet P \& Boutin JM 1999 Leuprolide acetate therapy in luteinizing hormone - dependent Cushing's syndrome. New England Journal of Medicine 341 1577-1581. (https://doi.org/10.1056/ NEJM199911183412104)

Lampron A, Bourdeau I, Hamet P, Tremblay J \& Lacroix A 2006 Whole genome expression profiling of glucose-dependent insulinotropic peptide (GIP)- and adrenocorticotropin-dependent adrenal hyperplasias reveals novel targets for the study of GIP-dependent Cushing's syndrome. Journal of Clinical Endocrinology and Metabolism 91 3611-3618. (https://doi.org/10.1210/jc.2006-0221)

Lee S, Hwang R, Lee J, Rhee Y, Kim DJ, Chung U-I \& Lim S-K 2005 Ectopic expression of vasopressin $\mathrm{V} 1 \mathrm{~b}$ and $\mathrm{V} 2$ receptors in the adrenal glands of familial ACTH-independent macronodular adrena hyperplasia. Clinical Endocrinology 63 625-630. (https://doi. org/10.1111/j.1365-2265.2005.02387.x)

Libé R \& Bertherat J 2005 Molecular genetics of adrenocortical tumours, from familial to sporadic diseases. European Journal of Endocrinology 153 477-487. (https://doi.org/10.1530/eje.1.02004)

Libè R, Fratticci A \& Bertherat J 2007 Adrenocortical cancer: pathophysiology and clinical management. Endocrine-Related Cancer 14 13-28. (https://doi.org/10.1677/erc.1.01130)

Libé R, Fratticci A, Coste J, Tissier F, Horvath A, Ragazzon B, ReneCorail F, Groussin L, Bertagna X, Raffin-Sanson ML, et al. 2008 Phosphodiesterase 11A (PDE11A) and genetic predisposition to adrenocortical tumors. Clinical Cancer Research 14 4016-4024. (https://doi.org/10.1158/1078-0432.CCR-08-0106)

Libé R, Coste J, Guignat L, Tissier F, Lefebvre H, Barrande G, Ajzenberg C, Tauveron I, Clauser E, Dousset B, et al. 2010 Aberrant cortisol regulations in bilateral macronodular adrenal hyperplasia: a frequent finding in a prospective study of 32 patients with overt or subclinical Cushing's syndrome. European Journal of Endocrinology 163 129-138. (https://doi.org/10.1530/EJE-10-0195)

Libé R, Horvath A, Vezzosi D, Fratticci A, Coste J, Perlemoine K, Ragazzon B, Guillaud-Bataille M, Groussin L, Clauser E, et al. 2011 Frequent phosphodiesterase 11A gene (PDE11A) defects in patients with carney complex (CNC) caused by PRKAR1A mutations: PDE11A may contribute to adrenal and testicular tumors in $\mathrm{CNC}$ as a modifier of the phenotype. Journal of Clinical Endocrinology and Metabolism 96 208-214. (https://doi.org/10.1210/jc.2010-1704)

Lodish M 2017 Genetics of adrenocortical development and tumors. Endocrinology and Metabolism Clinics of North America 46 419-433. (https://doi.org/10.1016/j.ecl.2017.01.007)

Louiset E, Duparc C, Young J, Renouf S, Tetsi Nomigni M, Boutelet I, Libé R, Bram Z, Groussin L, Caron P, et al. 2013 Intraadrenal corticotropin in bilateral macronodular adrenal hyperplasia. New England Journal of Medicine 369 2115-2125. (https://doi.org/10.1056/ NEJMoa1215245)

Lujambio A \& Lowe SW 2012 The microcosmos of cancer. Nature 482 347-355. (https://doi.org/10.1038/nature10888)

Mai PL, Best AF, Peters JA, DeCastro RM, Khincha PP, Loud JT, Bremer RC, Rosenberg PS \& Savage SA 2016 Risks of first and subsequent cancers among TP53 mutation carriers in the National Cancer Institute Li-Fraumeni syndrome cohort. Cancer 122 3673-3681. (https://doi.org/10.1002/cncr.30248)

Malkin D, Li FP, Strong LC, Fraumeni JF, Nelson CE, Kim DH, Kassel J, Gryka MA, Bischoff FZ \& Tainsky MA 1990 Germ line p53 mutations in a familial syndrome of breast cancer, sarcomas, and other neoplasms. Science 250 1233-1238. (https://doi.org/10.1126/ science.1978757)

Mansmann G, Lau J, Balk E, Rothberg M, Miyachi Y \& Bornstein SR 2004 The clinically inapparent adrenal mass: update in diagnosis and management. Endocrine Reviews 25 309-340. (https://doi. org/10.1210/er.2002-0031)

Marchesa P, Fazio VW, Church JM \& McGannon E 1997 Adrenal masses in patients with familial adenomatous polyposis. Diseases of the Colon and Rectum 40 1023-1028. (https://doi.org/10.1007/ BF02050923)

Matyakhina L, Freedman RJ, Bourdeau I, Wei MH, Stergiopoulos SG, Chidakel A, Walther M, Abu-Asab M, Tsokos M, Keil M, et al. 2005 Hereditary leiomyomatosis associated with bilateral, massive, macronodular adrenocortical disease and atypical cushing syndrome: a clinical and molecular genetic investigation. Journal of Clinical Endocrinology and Metabolism 90 3773-3779. (https://doi. org/10.1210/jc.2004-2377)

Miyamura N, Taguchi T, Murata Y, Taketa K, Iwashita S, Matsumoto K, Nishikawa T, Toyonaga T, Sakakida M \& Araki E 2002 Inherited adrenocorticotropin-independent macronodular adrenal hyperplasia with abnormal cortisol secretion by vasopressin and catecholamines: detection of the aberrant hormone receptors on adrenal gland. Endocrine 19 319-326. (https://doi.org/10.1385/ENDO:19:3:319)

Morin E, Mete O, Wasserman JD, Joshua AM, Asa SL \& Ezzat S 2012 Carney complex with adrenal cortical carcinoma. Journal of Clinical Endocrinology and Metabolism 97 202-206. (https://doi.org/10.1210/ jc.2011-2321)

Özata DM, Caramuta S, Velázquez-Fernández D, Akçakaya P, Xie H, Höög A, Zedenius J, Bäckdahl M, Larsson C \& Lui WO 2011 The role of microRNA deregulation in the pathogenesis of adrenocortical carcinoma. Endocrine-Related Cancer 18 643-655. (https://doi. org/10.1530/ERC-11-0082)

Patel D, Boufraqech M, Jain M, Zhang L, He M, Gesuwan K, Gulati N, Nilubol N, Fojo T \& Kebebew E 2013 MiR-34a and miR-483-5p are candidate serum biomarkers for adrenocortical tumors. Surgery $\mathbf{1 5 4}$ 1224-8; discussion 1229. (https://doi.org/10.1016/j. surg.2013.06.022)

Patronas Y, Horvath A, Greene E, Tsang K, Bimpaki E, Haran M Nesterova M \& Stratakis CA 2012 In vitro studies of novel PRKAR1A mutants that extend the predicted RI $\alpha$ protein sequence into the 3 '-untranslated open reading frame: proteasomal degradation leads to RI $\alpha$ haploinsufficiency and Carney complex. Journal of Clinical Endocrinology and Metabolism 97 E496-E502. (https://doi. org/10.1210/jc.2011-2220)
2018 Society for Endocrinology Published by Bioscientifica Ltd. Printed in Great Britain 
Patterson EE, Holloway AK, Weng J, Fojo T \& Kebebew E 2011 MicroRNA profiling of adrenocortical tumors reveals miR-483 as a marker of malignancy. Cancer 117 1630-1639. (https://doi. org/10.1002/cncr.25724)

Qiu W, Yang Z, Fan Y \& Zheng Q 2016 ZNRF3 is downregulated in papillary thyroid carcinoma and suppresses the proliferation and invasion of papillary thyroid cancer cells. Tumour Biology 37 12665-12672. (https://doi.org/10.1007/s13277-016-5250-4)

Ragazzon B, Libé R, Gaujoux S, Assié G, Fratticci A, Launay P, Clauser E, Bertagna X, Tissier F, de Reyniès A, et al. 2010 Transcriptome analysis reveals that p53 and \{beta\}-catenin alterations occur in a group of aggressive adrenocortical cancers. Cancer Research 70 8276-8281. (https://doi.org/10.1158/0008-5472.CAN-10-2014)

Ragazzon B, Libé R, Assié G, Tissier F, Barreau O, Houdayer C, Perlemoine K, Audebourg A, Clauser E, René-Corail F, et al. 2014 Mass-array screening of frequent mutations in cancers reveals RB1 alterations in aggressive adrenocortical carcinomas. European Journal of Endocrinology 170 385-391. (https://doi.org/10.1530/EJE-13-0778)

Raymond VM, Everett JN, Furtado LV, Gustafson SL, Jungbluth CR, Gruber SB, Hammer GD, Stoffel EM, Greenson JK, Giordano TJ, et al. 2013 Adrenocortical carcinoma is a lynch syndrome-associated cancer. Journal of Clinical Oncology 31 3012-3018. (https://doi. org/10.1200/JCO.2012.48.0988)

Rechache NS, Wang Y, Stevenson HS, Killian JK, Edelman DC, Merino M, Zhang L, Nilubol N, Stratakis CA, Meltzer PS, et al. 2012 DNA methylation profiling identifies global methylation differences and markers of adrenocortical tumors. Journal of Clinical Endocrinology and Metabolism 97 1004-1013. (https://doi. org/10.1210/jc.2011-3298)

Reincke M, Karl M, Travis WH, Mastorakos G, Allolio B, Linehan HM \& Chrousos GP 1994 p53 mutations in human adrenocortical neoplasms: immunohistochemical and molecular studies. Journal of Clinical Endocrinology and Metabolism 78 790-794. (https://doi. org/10.1210/jcem.78.3.8126158)

De Reyniès A, Assié G, Rickman DS, Tissier F, Groussin L, René-Corail F, Dousset B, Bertagna X, Clauser E \& Bertherat J 2009 Gene expression profiling reveals a new classification of adrenocortical tumors and identifies molecular predictors of malignancy and survival. Journal of Clinical Oncology 27 1108-1115. (https://doi.org/10.1200/ JCO.2008.18.5678)

Reznik Y, Allali-Zerah V, Chayvialle JA, Leroyer R, Leymarie P, Travert G, Lebrethon MC, Budi I, Balliere AM \& Mahoudeau J 1992 Fooddependent Cushing's syndrome mediated by aberrant adrenal sensitivity to gastric inhibitory polypeptide. New England Journal of Medicine 327 981-986. (https://doi.org/10.1056/ NEJM199210013271403)

Ronchi CL, Sbiera S, Leich E, Henzel K, Rosenwald A, Allolio B \& Fassnacht M 2013 Single nucleotide polymorphism array profiling of adrenocortical tumors - evidence for an adenoma carcinoma sequence? PLoS ONE 8 1-17. (https://doi.org/10.1371/journal. pone.0073959)

Ronchi CL, Di Dalmazi G, Faillot S, Sbiera S, Assié G, Weigand I, Calebiro D, Schwarzmayr T, Appenzeller S, Rubin B, et al. 2016 Genetic landscape of sporadic unilateral adrenocortical adenomas without PRKACA p.Leu206Arg mutation. Journal of Clinical Endocrinology and Metabolism 101 3526-3538. (https://doi. org/10.1210/jc.2016-1586)

Rothenbuhler A, Horvath A, Libé R, Faucz FR, Fratticci A, Raffin Sanson ML, Vezzosi D, Azevedo M, Levy I, Almeida MQ, et al. 2012 Identification of novel genetic variants in phosphodiesterase $8 \mathrm{~B}$ (PDE8B), a cAMP-specific phosphodiesterase highly expressed in the adrenal cortex, in a cohort of patients with adrenal tumours. Clinical Endocrinology 77 195-199. (https://doi. org/10.1111/j.1365-2265.2012.04366.x)

Sahut-Barnola I, de Joussineau C, Val P, Lambert-Langlais S, Damon C, Lefrançois-Martinez A-M, Pointud J-C, Marceau G, Sapin V, Tissier F, et al. 2010 Cushing's syndrome and fetal features resurgence in adrenal cortex-specific Prkar1a knockout mice. PLoS Genetics 6 e1000980. (https://doi.org/10.1371/journal.pgen.1000980)

Sato Y, Maekawa S, Ishii R, Sanada M, Morikawa T, Shiraishi Y, Yoshida K, Nagata Y, Sato-Otsubo A, Yoshizato T, et al. 2014 Recurrent somatic mutations underlie corticotropin-independent Cushing's syndrome. Science 344 917-920. (https://doi.org/10.1126/ science.1252328)

Schmitz KJ, Helwig J, Bertram S, Sheu SY, Suttorp AC, Seggewiss J, Willscher E, Walz MK, Worm K \& Schmid KW 2011 Differential expression of microRNA-675, microRNA-139-3p and microRNA-335 in benign and malignant adrenocortical tumours. Journal of Clinical Pathology 64 529-535. (https://doi.org/10.1136/jcp.2010.085621)

Shuch B, Ricketts CJ, Vocke CD, Valera VA, Chen CC, Gautam R, Gupta GN, Gomez MacIas GS, Merino MJ, Bratslavsky G, et al. 2013 Adrenal nodular hyperplasia in hereditary leiomyomatosis and renal cell cancer. Journal of Urology 189 430-435. (https://doi. org/10.1016/j.juro.2012.07.139)

Soon PSH, Tacon LJ, Gill AJ, Bambach CP, Sywak MS, Campbell PR, Yeh MW, Wong SG, Clifton-Bligh RJ, Robinson BG, et al. 2009 miR195 and miR-483-5p identified as predictors of poor prognosis in adrenocortical cancer. Clinical Cancer Research 15 7684-7692. (https://doi.org/10.1158/1078-0432.CCR-09-1587)

Stephan EA, Chung T-H, Grant CS, Kim S, Von Hoff DD, Trent JM \& Demeure MJ 2008 Adrenocortical carcinoma survival rates correlated to genomic copy number variants. Molecular Cancer Therapeutics 7 425-431. (https://doi.org/10.1158/1535-7163.MCT-07-0267)

Stratakis CA 2000 Genetics of Carney complex and related familial lentiginoses, and other multiple tumor syndromes. Frontiers in Bioscience 5 D353-D366. (https://doi. org/10.1080/15513810009168808)

Stratakis CA, Carney JA, Lin JP, Papanicolaou DA, Karl M, Kastner DL, Pras E \& Chrousos GP 1996 Carney complex, a familial multiple neoplasia and lentiginosis syndrome. Analysis of 11 kindreds and linkage to the short arm of chromosome 2. Journal of Clinical Investigation 97 699-705. (https://doi.org/10.1172/JCI118467)

Suzuki S, Tatsuno I, Oohara E, Nakayama A, Komai E, Shiga A, Kono T, Takiguchi T, Higuchi S, Sakuma I, et al. 2015 Germline deletion Of ARMC5 in familial primary macronodular adrenal hyperplasia. Endocrine Practice 21 1152-1160. (https://doi.org/10.4158/EP15756. OR)

Swords FM, Noon LA, King PJ \& Clark AJL 2004 Constitutive activation of the human ACTH receptor resulting from a synergistic interaction between two naturally occurring missense mutations in the MC2R gene. Molecular and Cellular Endocrinology 213 149-154. (https://doi. org/10.1016/j.mce.2003.10.052)

Szabó PM, Tamási V, Molnár V, Andrásfalvy M, Tömböl Z, Farkas R, Kövesdi K, Patócs A, Tóth M, Szalai C, et al. 2010 Meta-analysis of adrenocortical tumour genomics data: novel pathogenic pathways revealed. Oncogene 29 3163-3172. (https://doi.org/10.1038/ onc.2010.80)

Tadjine M, Lampron A, Ouadi L, Horvath A, Stratakis CA \& Bourdeau I 2008 Detection of somatic beta-catenin mutations in primary pigmented nodular adrenocortical disease (PPNAD). Clinical Endocrinology 69 367-373. (https://doi. org/10.1111/j.1365-2265.2008.03273.x)

Tissier F, Cavard C, Groussin L, Perlemoine K, Fumey G, Hagneré A-M, René-Corail F, Jullian E, Gicquel C, Bertagna X, et al. 2005 Mutations of beta-catenin in adrenocortical tumors: activation of the Wnt signaling pathway is a frequent event in both benign and malignant adrenocortical tumors. Cancer Research 65 7622-7627. (https://doi. org/10.1158/0008-5472.CAN-05-0593)

Tsai L-CL, Shimizu-Albergine M \& Beavo JA 2011 The high-affinity cAMP-specific phosphodiesterase $8 \mathrm{~B}$ controls steroidogenesis in the mouse adrenal gland. Molecular Pharmacology 79 639-648. (https:// doi.org/10.1124/mol.110.069104)
2018 Society for Endocrinology Published by Bioscientifica Ltd. Printed in Great Britain 
Weinstein LS, Shenker A, Gejman PV, Merino MJ, Friedman E \& Spiegel AM 1991 Activating mutations of the stimulatory G protein in the McCune-Albright syndrome. New England Journal of Medicine 325 1688-1695. (https://doi.org/10.1056/NEJM199112123252403)

Weksberg R, Shuman C \& Beckwith JB 2010 Beckwith-Wiedemann syndrome. European Journal of Human Genetics 18 8-14. (https://doi. org/10.1038/ejhg.2009.106)

Zhao J, Speel EJ, Muletta-Feurer S, Rütimann K, Saremaslani P, Roth J, Heitz PU \& Komminoth P 1999 Analysis of genomic alterations in sporadic adrenocortical lesions. Gain of chromosome 17 is an early event in adrenocortical tumorigenesis. American Journal of Pathology 155 1039-1045. (https://doi.org/10.1016/S0002-9440(10)65205-4)

Zheng S, Cherniack AD, Dewal N, Moffitt RA, Danilova L, Murray BA, Lerario AM, Else T, Knijnenburg TA, Ciriello G, et al. 2016 Comprehensive pan-genomic characterization of adrenocortical carcinoma. Cancer Cell 29 723-736. (https://doi.org/10.1016/j. ccell.2016.04.002)

Zhu J, Cui L, Wang W, Hang X-Y, Xu A-X, Yang S-X, Dou J-T, Mu Y-M, Zhang X \& Gao J-P 2013 Whole exome sequencing identifies mutation of EDNRA involved in ACTH-independent macronodular adrenal hyperplasia. Familial Cancer 12 657-667. (https://doi. org/10.1007/s10689-013-9642-y)

Received in final form 21 November 2017

Accepted 12 December 2017

Accepted Preprint published online 12 December 2017
(C) 2018 Society for Endocrinology Published by Bioscientifica Ltd. Printed in Great Britain 